\title{
5. UPPER CRETACEOUS CALCAREOUS NANNOFOSSILS FROM BROKEN RIDGE AND NINETYEAST RIDGE, INDIAN OCEAN ${ }^{1}$
}

\author{
Purtyasti Resiwati $^{2}$
}

\begin{abstract}
Drilling at Broken Ridge and Ninetyeast Ridge during Ocean Drilling Program Leg 121 yielded thick sections of Upper Cretaceous nannofossil-bearing sediments including calcareous chalk, limestone with chert, and volcanic ash.

The upper Campanian to Maestrichtian assemblages from Broken Ridge are austral in nature, containing many of the endemic Southern Ocean forms observed from the Falkland Plateau, Weddell Sea, and the Kerguelen Plateau. The absence of the Lithraphidites praequadratus- $L$. quadratus lineage and significant overlap of the first-appearance datum of Nephrolithus frequens and the last-appearance datum of Reinhardtites levis negate direct use of temperate zonation schemes for these sediments: the austral zonation is more effective but has lower stratigraphic resolution. The upper Campanian to Maestrichtian of Ninetyeast Ridge contains both austral and tropical forms in different horizons; the modified zonation of Sissingh (1977) is most effective in age-dating these sediments.

The Turonian-Santonian calcareous nannofossil assemblages are relatively sparse and poorly preserved. The absence of diagnostic species in the Turonian-Santonian sections is due to poor preservation and the unfavorable paleoenvironment of the rapid deposition of the thick ash in this interval. Biostratigraphic resolution is significantly impaired in this interval.
\end{abstract}

\section{INTRODUCTION}

Broken Ridge and Ninetyeast Ridge, along with the Kerguelen Plateau, have tectonic histories derived from the history of the Kerguelen/Ninetyeast Ridge hot spot in the context of the evolution of the Indian Ocean. Broken Ridge and Kerguelen Plateau were once a conjugate oceanic platform that formed from intraplate volcanism in the Early Cretaceous or mid-Cretaceous. Ninetyeast Ridge was interpreted to be a hot-spot trace of mid-Cretaceous to Oligocene age that was produced when the Kerguelen hot spot was either under the Indian plate, at the Indian plate boundary, or under portions of the Antarctic plate that were later transferred to the Indian plate by ridge jumps (Luyendyk, 1977; Luyendyk and Rennick, 1977; Peirce, 1978; Duncan, this volume; Royer et al., this volume).

Turonian to upper Maestrichtian nannofossil-bearing sediments were recovered from Sites $752-758$ drilled on Broken Ridge and Ninetyeast Ridge during Ocean Drilling Program (ODP) Leg 121 (Fig. 1), during May-June 1988. Turonian-lowermost Campanian calcareous nannofossils were recovered at Site 755. Upper Campanian-upper Maestrichtian assemblages were recovered from Sites 752, 754, and 758. The Upper Cretaceous nannofossil assemblages from Broken Ridge and Ninetyeast Ridge are unusual and important in that they are mixtures of taxa that are characteristic of both the austral and temperate areas. This provides an opportunity for correlation of zonation schemes derived separately from both realms. The purpose of this report is to document the variations of the Cretaceous calcareous nannofossil assemblages from the Leg 121 sites and to provide a more detailed biostratigraphic zonation than that possible during the limited time for shipboard study.

Numerous descriptive and stratigraphic studies have demonstrated significant paleobiogeographic effects on the distribution of Upper Cretaceous calcareous nannofossils. Worsley and Martini (1970) first recognized the provincial nature of the

\footnotetext{
'Weissel, J., Peirce, J., Taylor, E., Alt, J., et al., 1991. Proc. ODP. Sci. Results, 121: College Station, TX (Ocean Drilling Program).

2 Dept. of Geology, University of Nebraska, Lincoln, NE 68588-0340, U.S.A.
}

Maestrichtian nannofossils Micula murus (temperate) and Nephrolithus frequens ("polar"). Thierstein (1976) recognized that certain Cretaceous taxa have distinct distributions that are best explained by latitudinal preferences, leading him to define additional provincial Cretaceous taxa. Thierstein (1981) examined and quantitatively analyzed 243 upper Campanian through Maestrichtian assemblages and documented significant provinciality exhibiting strong paleolatitudinal variations. Two taxa were

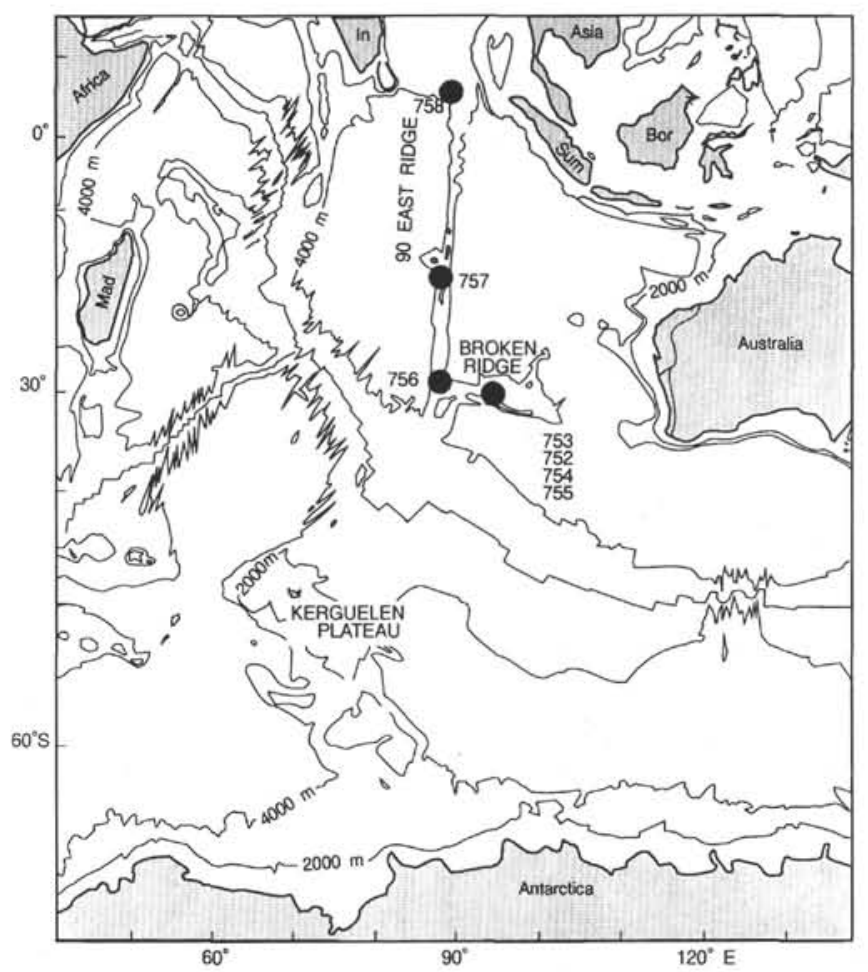

Figure 1. Location of Leg 121 sites. 
identified as distinctly tropical and eight as distinctly boreal/austral.

Drilling on the Falkland Plateau during Deep Sea Drilling Project (DSDP) Legs 36 and 71 recovered distinctive high-latitude calcareous nannofossil assemblages (Wise and Wind, 1977; Wind, 1979a, 1979b; Wise, 1983; Wind and Wise, 1983). Campanian to Maestrichtian calcareous nannofossils from the Falkland Plateau are characterized by assemblages of Kamptnerius magnificus, Monomarginatus spp., Nephrolithus spp., Eiffellithus turriseiffelii, and different species of Biscutum. The distinctive nature of these assemblages led Wind (1979a) to propose an austral upper Campanian to Maestrichtian zonation based largely on the distribution of Biscutum spp. Wind and Wise (1983) were able to correlate the Biscutum magnum and Biscutum coronum Zones to the Reinhardtites levis and Tranolithus phacelosus Zones (late Campanian to early Maestrichtian) of the temperate zonation of Sissingh $(1977,1978)$.

Wise (1988) summarized the results of deep-sea drilling in the Southern Ocean and proposed a comprehensive zonation for the austral Cretaceous. Comparison of the Upper Cretaceous part of Wise's zonation with those of Sissingh (1977) and Roth (1978), derived from temperate locations, illustrates the lack of direct correlation between austral and temperate zonation schemes (Fig. 2). This is especially true for the upper Campanian and Maestrichtian, which are characterized by strong latitudinal provincialism.

Recent results from the Southern Ocean have reinforced these contentions. Pospichal and Wise (1990) documented the dominantly austral assemblages from Maud Rise in the Weddell Sea.
They demonstrated that the upper two zones of the temperate zonation (Arkhangelskiella cymbiformis and Nephrolithus frequens Zones of Sissingh, 1977) could not be used in the southern Atlantic because of the markedly diachronous nature of the firstappearance datum (FAD) of $N$. frequens relative to the last-appearance datum (LAD) of $R$. levis. Watkins (in press) reached the same conclusion in his examination of assemblages from the central Kerguelen Plateau (Leg 120), where the FAD of $N$. frequens actually occurs prior to the LAD of $R$. levis.

These studies document the significant calcareous nannofossil provinciality that characterized the Campanian and Maestrichtian. Watkins (in press, table 4) summarized the paleobiogeographic affinities of key taxa for the Campanian-Maestrichtian of the Southern Hemisphere. His recommendations have been followed herein to assign paleobiogeographic affinities to specific taxa. The term "low latitude" is used to refer to taxa that are common in tropical and/or temperate $\left(<45^{\circ}\right.$ paleolatitude $)$ assemblages but absent or much less abundant in high-latitude assemblages. The reverse is true for usage of the term "high latitude." The term "austral" is reserved for those species that were restricted to the southern high latitudes during the CampanianMaestrichtian.

\section{METHOD AND PROCEDURES}

Smear slides were prepared from raw sediment samples and examined using the polarizing light microscope to define the calcareous nannofossil assemblages. Tables 1-5 show the distribution and the preservational state of the nannofossils in the samples examined. The estimation of the abundance of calcareous

\section{AUSTRAL}

TEMPERATE

\begin{tabular}{|c|c|c|c|c|c|c|c|}
\hline & & \multicolumn{2}{|c|}{$\begin{array}{c}\text { Wise (1988) } \\
\text { Pospichal and Wise (1990) }\end{array}$} & \multicolumn{2}{|c|}{$\begin{array}{c}\text { Sissingh (1977) } \\
\text { Perch-Nielsen (1985) }\end{array}$} & \multicolumn{2}{|l|}{ Roth (1978) } \\
\hline \multirow{5}{*}{ 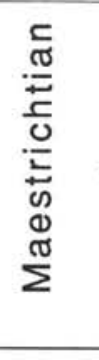 } & \multirow{3}{*}{1} & \multirow{3}{*}{$\begin{array}{l}\text { Nephrolithus } \\
\text { sp. }\end{array}$} & \multirow{2}{*}{ C. daniae } & N. frequens & $\mathrm{cc} 26$ & $\begin{array}{l}\text { M. murus/ } \\
\text { N. frequens }\end{array}$ & $\mathrm{NC23}$ \\
\hline & & & & \multirow[t]{2}{*}{ A. cymbiformis } & \multirow[t]{2}{*}{$\mathrm{CC} 25$} & L. quadratus & NC22 \\
\hline & & & N. corystus & & & \multirow[b]{2}{*}{ L. praequadratus } & \multirow[b]{2}{*}{ NC21 } \\
\hline & \multirow{2}{*}{ e } & \multicolumn{2}{|c|}{ B. magnum } & R. levis & $\mathrm{CC} 24$ & & \\
\hline & & \multirow{5}{*}{\multicolumn{2}{|c|}{$\begin{array}{c}B . \\
\text { coronum }\end{array}$}} & \multirow[t]{2}{*}{ T. phacelosus } & \multirow[t]{2}{*}{$\mathrm{CC23}$} & \multirow{3}{*}{ T. trifidus } & \multirow{3}{*}{ NC20 } \\
\hline \multirow{6}{*}{ 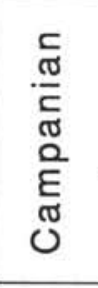 } & \multirow{6}{*}{1} & & & & & & \\
\hline & & & & Q. trifidum & $\mathrm{CC22}$ & & \\
\hline & & & & \multirow{2}{*}{$\begin{array}{c}\text { Q. sissinghi } \\
\text { C. aculeus } \\
\text { C. ovalis }\end{array}$} & \multirow{2}{*}{$\begin{array}{l}\text { CC21 } \\
\text { CC20 } \\
\text { CC19 } \\
\end{array}$} & T. aculeus & NC19 \\
\hline & & & & & & \multirow{2}{*}{ B. parca } & \multirow{2}{*}{ NC18 } \\
\hline & & \multirow{2}{*}{$\begin{array}{c}\text { M. } \\
\text { furcatus }\end{array}$} & G. diabolum & A. parcus & CC18 & & \\
\hline & & & G. costatum & C. obscurus & $\mathrm{CC} 17$ & \multirow{3}{*}{$\begin{array}{l}T . \text { obscurus- } \\
\dot{M} \text {. concava }\end{array}$} & \multirow{3}{*}{ NC17 } \\
\hline \multirow{3}{*}{$\underset{\text { ஸ் }}{\stackrel{+}{C}}$} & \multirow{2}{*}{1} & \multirow{2}{*}{\multicolumn{2}{|c|}{ E. floralis }} & L. cayeuxii & $\mathrm{CC} 16$ & & \\
\hline & & & & R. anthophorus & CC15 & & \\
\hline & $\theta$ & T. ecc & siastica & M. decussata & CC14 & B. lacunosa & NC16 \\
\hline Con. & 1 & & & M. furcatus & $\mathrm{CC} 13$ & M. furcatus & NC15 \\
\hline Tur. & $\frac{1}{m}$ & magr & cus & L. maleformis & $\mathrm{CC} 12$ & K. magnificus & NC14 \\
\hline & e & E. tur & eiffelii & Q. gartneri & CC11 & M. staurophora & NC13 \\
\hline
\end{tabular}

Figure 2. Comparison of nannofossil zonation schemes for the Upper Cretaceous. 
nannofossils as a sediment component in the slide follows Watkins and Bowdler (1984):

$\mathrm{A}=$ abundant (nannofossils comprise $>15 \%$ of the sediment); $\mathrm{C}=$ common (nannofossils comprise $15 \%-5 \%$ of the sediment);

$\mathrm{F}=$ few (nannofossils comprise $5 \%-1 \%$ of the sediment);

$\mathrm{R}=$ rare (nannofossils comprise $<1 \%$ of sediment);

EB $=$ essentially barren (nannofossils comprise $<<1 \%$ of the sediment, typically with fewer than 10 specimens per 100 fields of view at $1560 \times)$;

$\mathrm{B}=$ barren (no nannofossils observed in 100 fields of view at $1560 \times)$

The abundance of individual species is estimated using Hay's (1970) method as modified by Watkins and Bowdler (1984):

$\mathrm{A}=$ abundant (at least 1 specimen per field of view at $1500 \mathrm{x}$ );

$\mathrm{C}=$ common $(1$ specimen per $2-10$ fields of view at $1500 \mathrm{x}$ );

$\mathrm{F}=$ few $(1$ specimen per 11-100 fields of view at $1500 \times)$;

$\mathrm{R}=$ rare $(1$ specimen per 101-1000 fields of view at $1500 \mathrm{x})$;

$?=$ questionable presence of the species.

The state of preservation of the nannofossils was analyzed with a qualitative standard as follows:

$\mathrm{G}=\operatorname{good}($ specimens exhibit little or no secondary alteration);

$\mathrm{M}=$ moderate (specimens exhibit the effects of secondary alteration from etching and or overgrowth; identification of species not impaired);

$\mathrm{P}=$ poor (specimens exhibit profound effects of secondary alteration from etching and overgrowth; identification of species impaired).

Most of the calcareous nannofossils from the study area are poorly preserved; the scanning electron microscope (SEM) was used to examine some doubtful, poorly preserved forms.

\section{BIOSTRATIGRAPHIC ZONATION}

No single published Upper Cretaceous calcareous nannofossil zonation scheme can be used with full reliability because of the unusual mixture of low- and high-latitude forms found at Broken Ridge and, to a lesser degree, at the northern Ninetyeast Ridge sites. This is especially true of the upper Campanian and Maestrichtian sections. The zonation of Roth (1978) uses the FADs of Nephrolithus frequens and Micula murus (assumed to be simultaneous), Lithraphidites quadratus, Lithraphidites praequadratus, and Quadrum trifidum as markers for his NC zones (Fig. 2). Pospichal and Wise (1990) and Watkins (in press) demonstrated that the FAD of $N$. frequens is markedly diachronous in the Southern Ocean, approaching and even overlapping with that of Reinhardtites levis. This phenomenon is evident in the Maestrichtian of Sites 752 and 754 on Broken Ridge (as described in the following), rendering the FAD of $N$. frequens dubious for correlation. $M$. murus is seen only at the top of the Maestrichtian sequence at Site 758 (Ninetyeast Ridge). L. quadratus occurs only sporadically at Sites 752 and 758 and not at all at Site 754. L. praequadratus was not recognized reliably at any of the Maestrichtian sites on Leg 121, although other evidence indicates that sediments of the appropriate age are present at Sites 752 and 758. Q. trifidum and Quadrum sissinghii were present in reliable abundances at Site 758, but absent in coeval material from Site 752 .

The calcareous nannofossil zonation scheme of Sissingh (1977) is the most appropriate one for the Turonian to Santonian assemblages from Site 755, but is less useful for the upper Campanian and Maestrichtian material. The reliance on the FAD of $N$. frequens (Fig. 2) for the upper Maestrichtian of the Sissingh (1977) zonation makes direct correlation with austral assemblages impossible (Pospichal and Wise, 1990; Watkins, in press). The LADs of $R$. levis and Tranolithus phacelosus appear to be reliable in both austral and temperate regions, although the FAD of $Q$. trifidum is useful only in temperate material (Wind and Wise, 1983; Watkins, in press).

The austral zonation of Wise (1988) is useful for the upper Campanian and Maestrichtian of the Broken Ridge sites, but is less applicable to Site 758 on Ninetyeast Ridge. This zonation (Fig. 2) relies heavily on the distribution of the high-latitude Biscutum species $B$. magnum and $B$. coronum, while avoiding the problem of $N$. frequens diachroneity. However, this heavy reliance on austral taxa limits its utility at Site 758 , where the high-latitude Biscutum species are sporadic in occurrence.

In order to overcome some of these problems, I have chosen to use both the Sissingh (1977) and Wise (1988) zonations for the upper Campanian and Maestrichtian material from Broken Ridge. The Sissingh (1977) zonation is used for the low-latitude $\left(5^{\circ} \mathrm{N}\right)$ material from Site 758 (Ninetyeast Ridge) and for the Turonian to Santonian material from Site 755. Modifications of the Sissingh (1977) zonation by Perch-Nielsen (1985) are used when additional biostratigraphic resolution is gained (as noted in the following "Site Summaries"). In addition, the upper two zones of the Sissingh (1977) zonation (the Arkhangelskiella cymbiformis and $N$. frequens Zones) are combined because of the unreliability of the FAD of $N$. frequens in the australly influenced assemblages from Broken Ridge. The LAD of $R$. levis is used to separate the combined A. cymbiformis/N. frequens Zone from the underlying $R$. levis Zone. The correlation of zones with Cretaceous stages is based on Perch-Nielsen $(1979,1985)$ unless otherwise mentioned in the text. The correlation of the stage to the absolute time scale is based on Kent and Gradstein (1985).

\section{SITE SUMMARIES}

\section{Site 752}

Site 752 lies near the crest of Broken Ridge, about $16 \mathrm{~km}$ north of the main southward-facing escarpment (Fig. 3). Two holes were drilled at this site. Hole $752 \mathrm{~B}$ was drilled at $30^{\circ} 53.483^{\prime} \mathrm{S}$, $93^{\circ} 34.652^{\prime} \mathrm{E}$, in a water depth of $1086.3 \mathrm{~m}$.

Upper Maestrichtian sediments were recovered in the interval between Sample 121-752B-11R-3, 73-74 cm, and the base of the section at this site. The Cretaceous section at Site 752, designated lithologic Subunit IIC (Peirce, Weissel, et al., 1989), consists of faintly mottled, light gray to light greenish hard chalk, characterized by cross-bedding, burrows, and some curved structures around shell fragments.

The Cretaceous calcareous nannofossils from this site generally exhibit moderate preservation. Some specimens suffer from overgrowth and etching, and some are broken. The nannofossils are rare to few in the uppermost part of the section (near the Cretaceous/Tertiary boundary) but are abundant to common in the majority of the section. The assemblages are relatively diverse in most of the section, except in the uppermost section, close to the Cretaceous/Tertiary boundary, where the assemblages contain only a few taxa. A complete Cretaceous/Tertiary boundary was recovered at Site 752 . The Cretaceous/Tertiary boundary of this site is within Sample 121-752B-11R-3, 72-73 cm, based on the first occurrence of Biantholithus sparsus (Pospichal, 1989).

In general, the calcareous nannofossil assemblages are moderately diverse. They are dominated by austral and cosmopolitan taxa. High-latitude taxa present include Misceomarginatus pleniporus, Monomarginatus pectinatus, and Biscutum magnum (Table 1). Kamptnerius magnificus is abundant, as is typical of high-latitude assemblages. Watznaueria barnesae is very rare in the uppermost part of the section, and becomes common in the lower part of the section.

The interval between Samples 121-752B-11R-3, 73-74 cm, and $121-752 \mathrm{~B}-17 \mathrm{R}-3,105-106 \mathrm{~cm}$, can be assigned to the combined Arkhangelskiella cymbiformis/Nephrolithus frequens Zone 


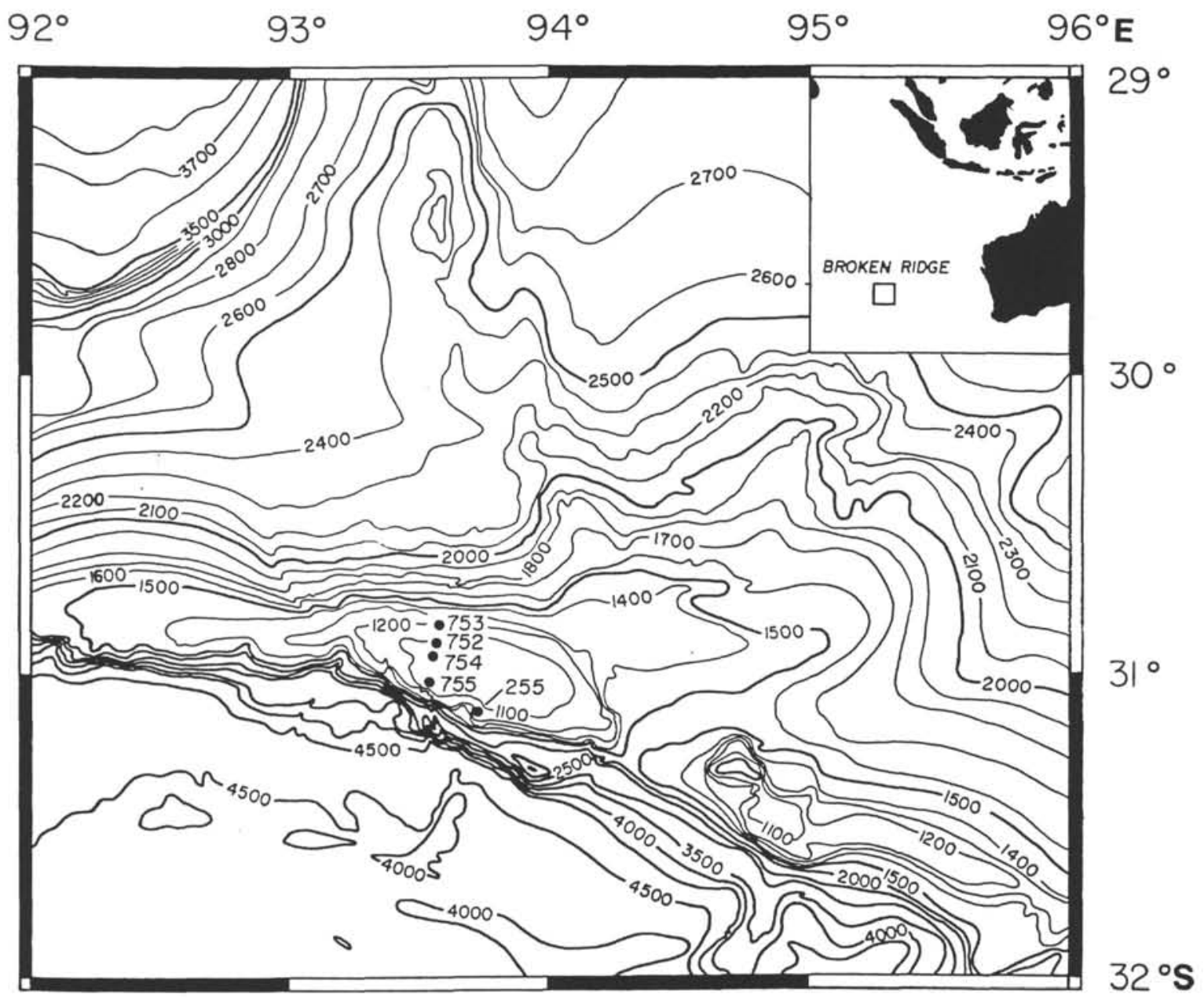

Figure 3. Leg 121 Broken Ridge Sites 752-755 (after Peirce, Weissel, et al., 1989).

of late Maestrichtian age based on the occurrence of $N$. frequens and Lithraphidites quadratus without Reinhardtites levis (CC25b-26, sensu Perch-Nielsen, 1985). The FAD of $N$. frequens can not be used in this section as $N$. frequens is found from the top of the Cretaceous down to below the last occurrence of $R$. levis. L. quadratus is very rare and inconsistent. Micula murus, a taxon that is usually found in the uppermost Maestrichtian of low-latitude assemblages, is apparently absent at this site.

The interval from Sample 121-752B-17R-3, 105-106 cm, through Section 121-752B-19R-CC contains $R$. levis (Table 1), indicating the R. levis Zone of Sissingh (1977). The presence of high-latitude taxa such as B. magnum, Cribrosphaerella daniae, and Nephrolithus corystus, as well as high abundances of $K$. magnificus and low abundances of $W$. barnesae, indicate the strongly austral affinities of these assemblages.

The use of the austral zonation of Wise (1988) reveals two zones in the Maestrichtian of Site 752. The interval from Samples 121-752B-11R-3, 73-74 cm, to 121-752B-16R-3, 103-104 cm, is assigned to the $N$. frequens Zone of Wise (1988) based on the presence of $N$. frequens without $B$. magnum or $R$. levis. This interval can be subdivided by use of the LAD of $N$. corystus, following the practice of Pospichal and Wise (1990). The LAD of $N$. corystus occurs at Sample 121-752B-13R-6, 42-43 cm.

The interval from Sample 121-752B-16R-CC through Section 121-752B-19R-CC contains B. magnum and N. corystus, indicating the B. magnum Zone (mid-Maestrichtian) of Wise (1988). The occurrence of $B$. magnum, $N$. corystus, Monomarginatus spp., Misceomarginatus pleniporus, and Cribrosphaerella daniae, as well as the high abundance of $K$. magnificus and the paucity of $W$. barnesae, indicates the austral affinities of these assemblages.

\section{Site 754}

Site 754 is approximately $14 \mathrm{~km}$ north of the south-facing escarpment of Broken Ridge on the transect of drilled sites across the crest of the ridge (Fig. 3). Two holes were drilled at the site. The approximately $20 \mathrm{~m}$ of lower Maestrichtian sediment recovered from Hole $754 \mathrm{~A}$ in Cores $121-754 \mathrm{~A}-17 \mathrm{~N}$ to $121-754 \mathrm{~A}-23 \mathrm{~N}$ unconformably underlies the thick Cenozoic chalk section. The unconformable boundary of the Cretaceous and the Cenozoic is marked by loose "beachtype" chert gravel. Drilling at Hole 754A was terminated at $172.1 \mathrm{~m}$ below seafloor (mbsf) after five cores were recovered.

Hole 754B was washed down to the upper Eocene chalk. Chert gravel was encountered just above the Cretaceous sediments. Approximately $200 \mathrm{~m}$ of Cretaceous section was recovered in Cores 121-754B-5R to 121-754B-25R.

Three major lithologic subunits were designated in this Cretaceous section (Peirce, Weissel, et al., 1989). Uppermost Subunit IIA is a light gray to greenish gray chalk with planar and crossbedded laminae that unconformably underlies the Tertiary. This subunit contains moderately to poorly preserved but common to abundant nannofossils. Subunit IIB consists of limestone with dark ash layers and chert pebbles. The calcareous nannofossils from this subunit are very rare and show moderate to poor preservation. Subunit IIC, the lowermost subunit at Site 754B, consists of alternating chert and weakly laminated and mottled gray 
to olive limestone. Calcareous nannofossils are very rare and poorly preserved in this subunit; some samples are barren.

The nannofossil assemblages are relatively diverse in the chalk and limestone subunits, becoming very sparse to barren in the alternating limestone and chert subunit (Tables 2 and 3). Many specimens suffer from overgrowth or etching. For example, many specimens of the genus Nephrolithus are overgrown or are missing the central area as a result of dissolution, leaving the vacant outer shield. This makes species assignment difficult. Kamptnerius magnificus, Repagalum parvidentatum, Misceomarginatus pleniporus, Monomarginatus pectinatus, Biscutum magnum, Biscutum constans, and Biscutum dissimilis are common constituents of these assemblages, indicating austral affinities. Calculites obscurus is common in the upper part of the section but becomes scarce in the lower part of the section (as the lithology changes into chalk and limestone), and it is absent in the chert-bearing limestone subunit.

Reinhardtites levis is found in all samples throughout the sequence at Site 754 . Cores $121-754 \mathrm{~A}-17 \mathrm{~N}$ to $121-754 \mathrm{~A}-23 \mathrm{~N}$ and the interval from Samples 121-754B-5R-1, 0-1 cm, to 121-754B$12 \mathrm{R}-1,42-43 \mathrm{~cm}$, are assigned to the $R$. levis Zone $(\mathrm{CC} 24)$ of Sissingh (1977) based on the occurrence of $R$. levis and the absence of Tranolithus phacelosus. The interval from Sample 121-754B-12R-1, 42-43 cm, to the base of the section (Core $121-754 \mathrm{~B}-25 \mathrm{R}$ ) is characterized by the same assemblage with the addition of $T$. phacelosus, placing it in the upper $T$. phacelosus Zone (lower Maestrichtian) of Sissingh (1977). Very rare specimens of Aspidolithus parcus constrictus occur in Samples 121754B-24R-2, 20-21 cm, and 121-754B-25R-CC. These are believed to be reworked from other localities. The specimens assigned as Reinhardtites anthophorus during the shipboard work are more accurately classified as Reinhardtites sp. aff. $R$. anthophorus of Sissingh (1977) (Pl. 4, Fig. 4). This interval is correlated to paleomagnetic Chron 32 (Gee et al., this volume).

Two of the austral zones of Wise (1988) are recognized within the section at Site 754: the lower Biscutum coronum Zone and the upper B. magnum Zone. Cores 121-754A-17N to $121-754 \mathrm{~A}-23 \mathrm{~N}$ and the interval from Core 121-754B-5R to Sample 121-754B$9 \mathrm{R}-5,118-120 \mathrm{~cm}$, are placed in the austral $B$. magnum Zone based on the presence of $B$. magnum without $B$. coronum. The underlying interval from Section 121-754B-9R-CC through Core 121-754B-25R (total depth) contains both $B$. magnum and $B$. coronum, indicating the $B$. coronum Zone (lower Maestrichtian).

\section{Site 755}

Site 755 is about $4 \mathrm{~km}$ north of the south-facing escarpment of Broken Ridge, in a water depth of about $1057.9 \mathrm{~m}$ (Fig. 2). The objective of drilling at this site was to recover a particularly prominent seismic reflector that crops out at the tip of Broken Ridge. Owing to time constraints, however, drilling at Site 755 was terminated after penetrating to $208 \mathrm{mbsf}$.

Three major lithologic subunits of Turonian to early Campanian age were recovered from Site 755 (Peirce, Weissel, et al., 1989). The uppermost Subunit IIA was recovered in Cores 121$755 \mathrm{~A}-5 \mathrm{R}$ to $121-755 \mathrm{~A}-12 \mathrm{R}$ after penetrating a middle Miocene shelly, foraminiferal grainstone layer in the bottom of Core 121$755 \mathrm{~A}-4 \mathrm{R}$. Subunit IIA consists of gray to greenish volcanic ash interbedded with ashy limestone containing a trace of glauconite. Subunit IIB (Cores 121-755A-13R to 121-755A-17R) is volcanic ash that contains variable amounts of glauconite. Core 121-755A$18 \mathrm{R}$ to the bottom of the hole (Core 121-755A-19R) composes Subunit IIC, which consists of dark greenish gray tuffs with varying amounts of micrite.

The ash-rich Cretaceous sediments at Site 755 contain poorly preserved and very sparse assemblages of calcareous nannofossils (Table 4$)$. The nannofossils are very rare in most of the section and Subunit IIC is sporadically barren. The poor preservation and low abundances make biostratigraphic assignment difficult.

The interval from Samples 121-755A-5R-1, 36-38 cm, to 121-755A-5R-1, 89-90 cm, contains assemblages with Calculites obscurus, Lucianorhabdus cayeuxii, and Aspidolithus parcus, indicating the $C$. obscurus Zone (CC17; lowermost Campanian). One of the most common taxa in these assemblages is Helicolithus trabeculatus. Watkins et al. (1989) and Watkins (in press) noted that this species commonly exhibits an abundance peak near the Santonian/Campanian boundary in Southern Ocean assemblages. If this is true for Broken Ridge (as it is for its conjugate, the Kerguelen Plateau), it implies that this interval lies near the Santonian/Campanian boundary.

The interval from Sample 121-755A-5R-2, 40-41 cm, through Core $121-755 \mathrm{~A}-7 \mathrm{R}$ is assigned to the Lucianorhabdus cayeuxii Zone (CC16; upper Santonian). This zone is characterized by the occurrence of Broinsonia furtiva, A. parcus, L. cayeuxii, and Quadrum gartneri. The latter two taxa are very rare. Marthasterites furcatus, a taxon generally seen in coeval assemblages, was observed only in Samples 121-755A-6R-1, 14-15 cm, and 121$755 \mathrm{~A}-6 \mathrm{R}-3,46-47 \mathrm{~cm}$. Watkins (in press) noted that $M$. furcatus is rare to absent in coeval assemblages of the conjugate Kerguelen Plateau.

The interval from Core 121-755A-8R through Sample 121$755 \mathrm{~A}-10 \mathrm{R}-2,21-22 \mathrm{~cm}$, is in the Reinhardtites anthophorus Zone (CC15) of the upper Santonian. This zone is characterized by the occurrence of $R$. anthophorus without $L$. cayeuxii. Nannofossil abundance and preservation are poor in this interval.

The interval from Sample 121-755A-10R-2, 21-22 cm, through Core 121-755A-11R is assigned to the Micula decussata Zone (CC14; uppermost Coniacian to lower Santonian) based on the presence of the nominate taxon in the absence of $R$. anthophorus. The Coniacian/Santonian boundary is in this zone, slightly above the first occurrence of $M$. decussata. $M$. furcatus, $\mathrm{Lu}$ cianorhabdus maleformis, Eprolithus floralis, and Q. gartneri are poorly preserved and very rare in this section.

The underlying sequence is characterized by ash-rich sediments barren of nannofossils or containing poorly preserved, sparse assemblages only. The lack of $M$. decussata from Core 121-755A-13R through the base of the section (Core 121-755A19R) indicates a pre-early Coniacian age for these sediments. Although they occur inconsistently, E. floralis, Eprolithus floralis sp. 1, Eprolithus floralis sp. 2, and Lithastrinus moratus are present in this interval. These species are typical of the L. maleformis Zone $(\mathrm{CC} 12)$ of the upper Turonian, although the $M$. furcatus Zone (CC13; lower Coniacian) may be present, as the lack of $M$. furcatus in this interval may be due to the paleoenvironmental restrictions. The presence of $K$. magnificus, Gartnerago obliquum, and Eiffellithus eximius indicates that the lowermost part of the section is still Turonian.

\section{Site 758}

Site 758 is the only site drilled on the Ninetyeast Ridge during Leg 121 that penetrated Cretaceous sediments. This site lies along the crest of Ninetyeast Ridge, midway between DSDP Sites 216 and 217. Hole 758A, which penetrated the Cretaceous, is at $5^{\circ} 23.049^{\prime} \mathrm{N}, 90^{\circ} 21.673^{\prime} \mathrm{E}$, in a water depth of $2923.6 \mathrm{~m}$. Total penetration at Hole $758 \mathrm{~A}$ was $453.83 \mathrm{mbsf}$. Four lithologic units were designated in the approximately $230 \mathrm{~m}$ of upper Campanian to upper Maestrichtian sediments recovered (Peirce, Weissel, et al., 1989). The Cretaceous calcareous nannofossil assemblages in this section are more diverse than those found at the Broken Ridge sites, as a result of the addition of some low-latitude forms on Ninetyeast Ridge. Taxa characteristic of high-latitude, such as Biscutum magnum, Biscutum dissimilis, Biscutum constans, Misceomarginatus pleniporus, Monomarginatus pectinatus, and Rep- 
Table 1. Maestrichtian calcareous nannofossils, Hole 752B.

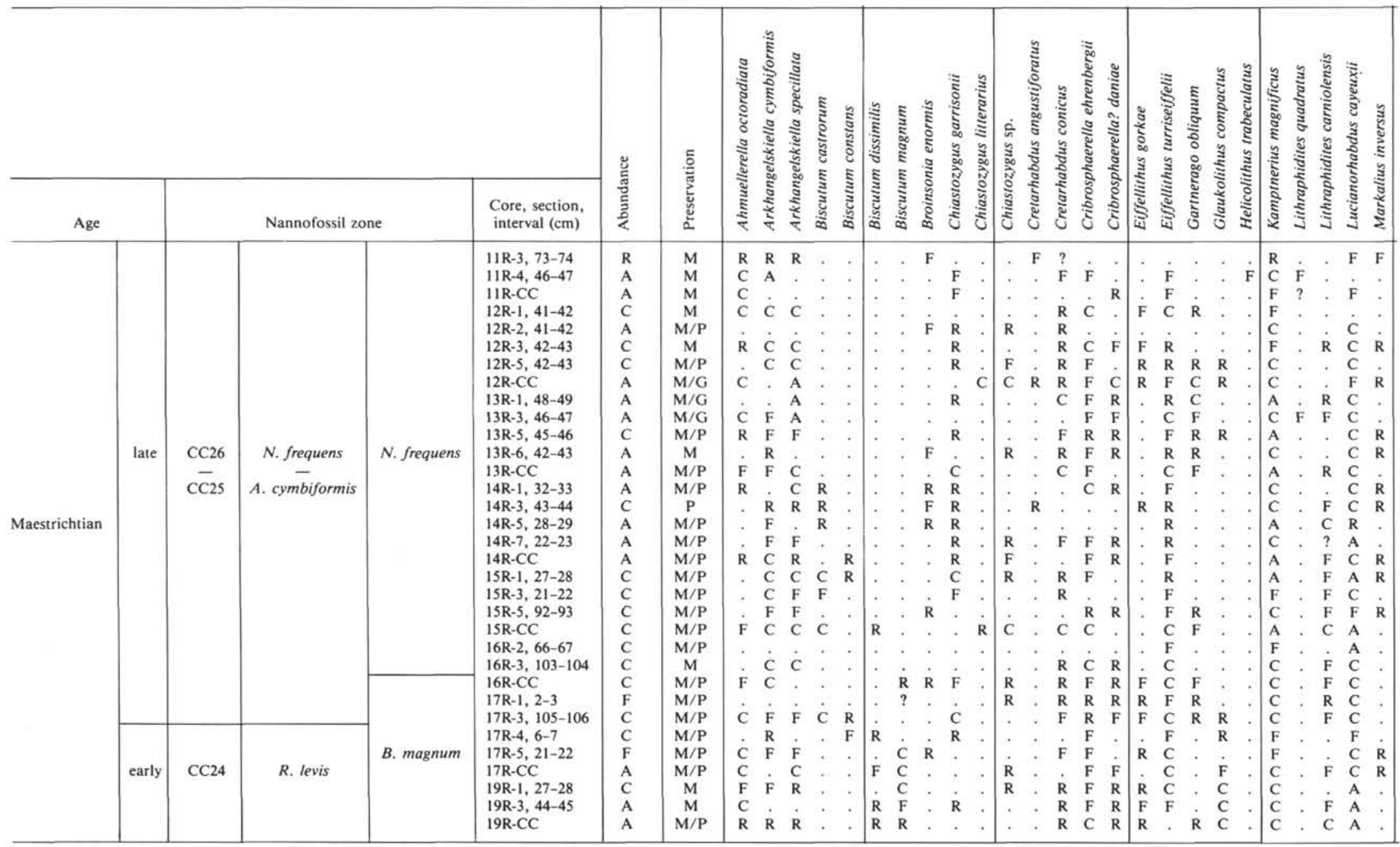

Note: Preservation: $\mathrm{G}=$ good, $\mathrm{M}=$ moderate, $\mathrm{P}=$ poor. Abundance: $\mathrm{A}=$ abundant, $\mathrm{C}=$ common, $\mathrm{F}=\mathrm{few}, \mathrm{R}=$ rare, ? $=$ questionably present, $\mathrm{B}=$ barren, . $=$ not present. 


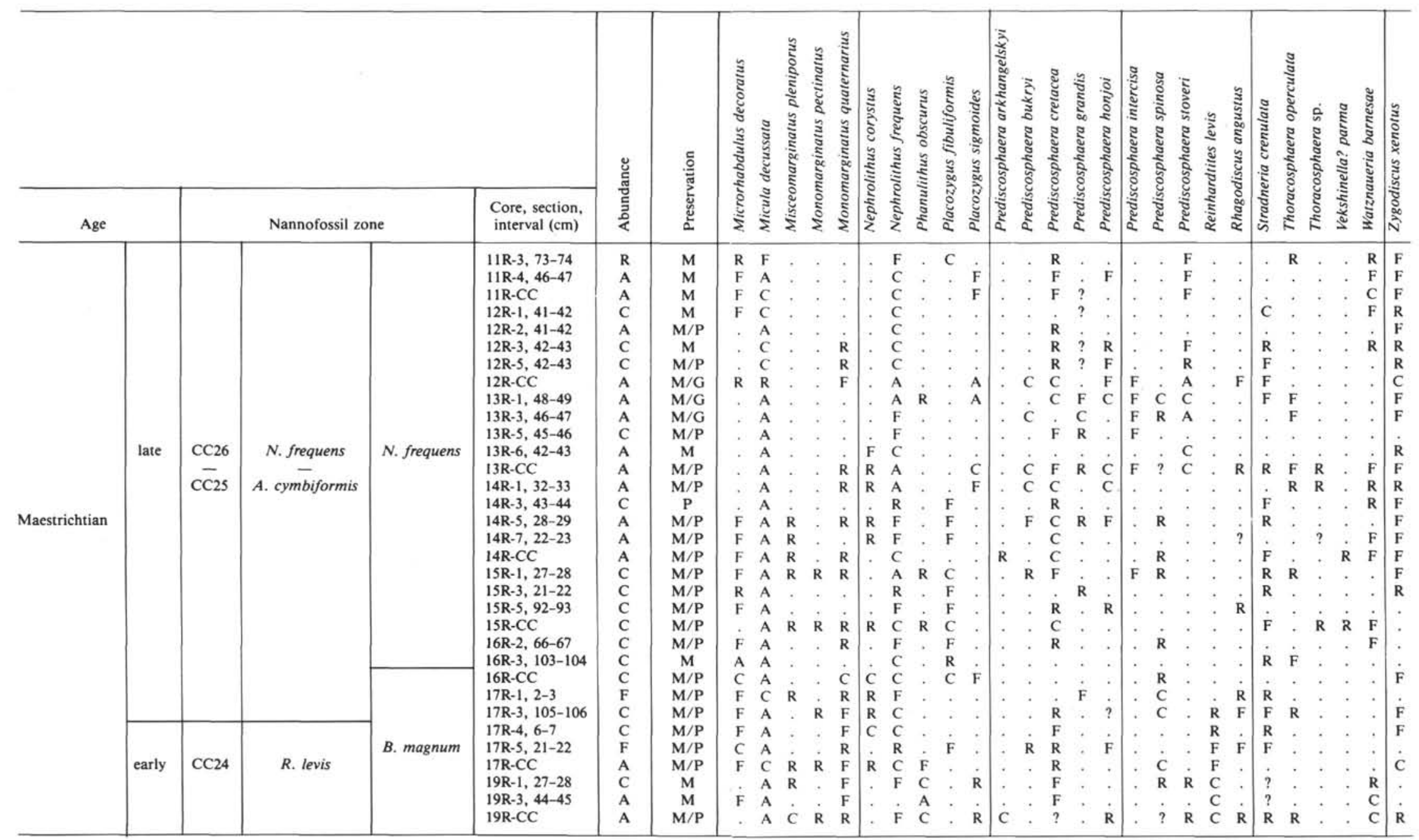




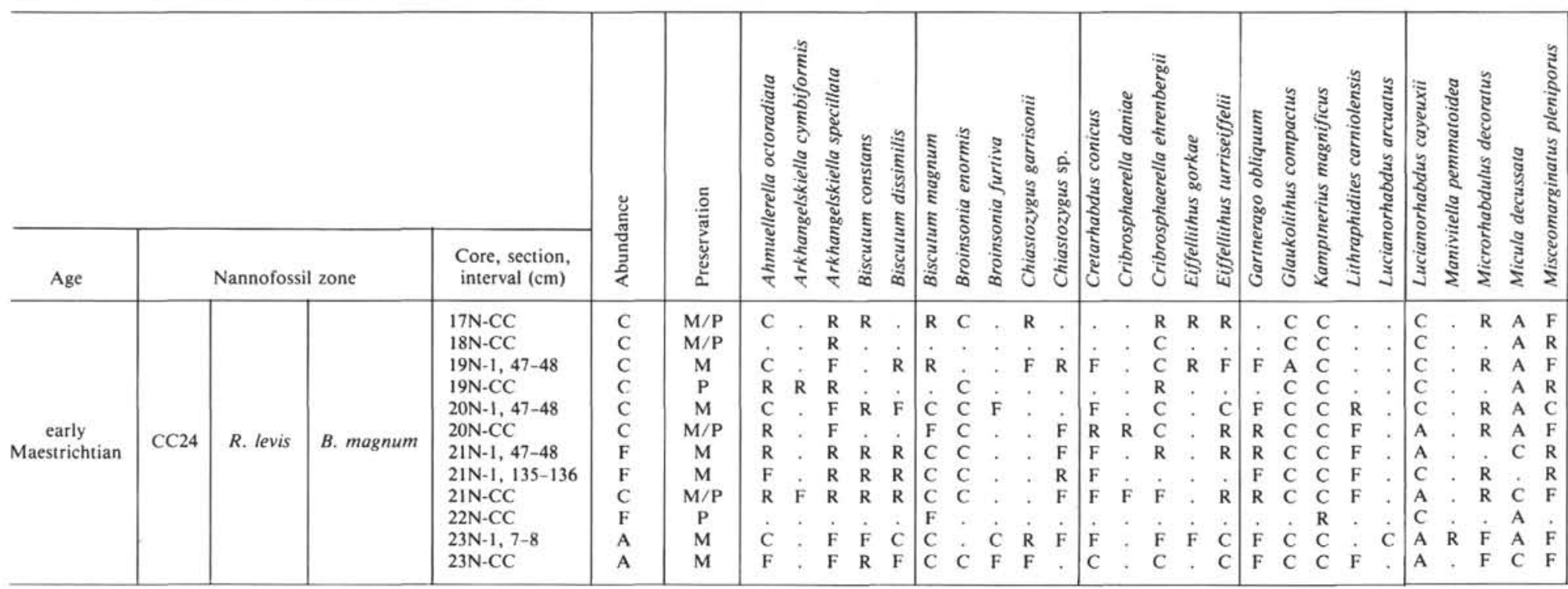

Note: Preservation: $\mathbf{G}=$ good, $\mathbf{M}=$ moderate, $\mathbf{P}=$ poor. Abundance: $\mathbf{A}=$ abundant, $\mathrm{C}=$ common, $\mathbf{F}=$ few, $\mathbf{R}=$ rare, ? $=$ questionably present, $\mathbf{B}=$ barren,.$=$ not present.

\begin{tabular}{|c|c|c|c|c|c|c|c|c|c|c|c|c|c|c|c|c|c|c|c|c|c|c|c|c|}
\hline Age & & Nannofossi & zone & $\begin{array}{l}\text { Core, section, } \\
\text { interval }(\mathrm{cm})\end{array}$ & 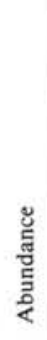 & 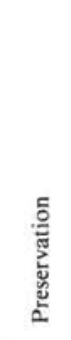 & 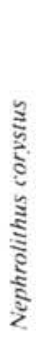 & 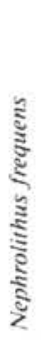 & 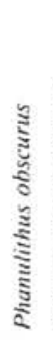 & 离 & : & 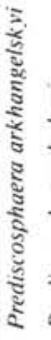 & 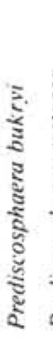 & 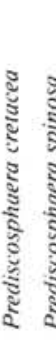 & 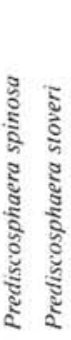 & $\mid$ & 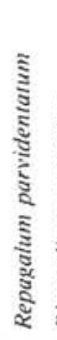 & 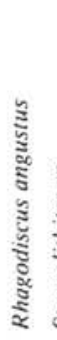 & 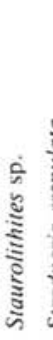 & 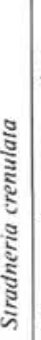 & 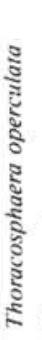 & 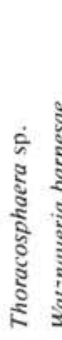 & 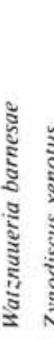 & 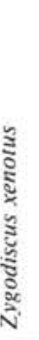 \\
\hline $\begin{array}{c}\text { early } \\
\text { Maestrichtian }\end{array}$ & $\mathrm{CC} 24$ & $R$, levis & B. magnum & $\begin{array}{l}17 \mathrm{~N}-\mathrm{CC} \\
18 \mathrm{~N}-\mathrm{CC} \\
19 \mathrm{~N}-1,47-48 \\
19 \mathrm{~N}-\mathrm{CC} \\
20 \mathrm{~N}-1,47-48 \\
20 \mathrm{~N}-\mathrm{CC} \\
21 \mathrm{~N}-1,47-48 \\
21 \mathrm{~N}-1,135-136 \\
21 \mathrm{~N}-\mathrm{CC} \\
22 \mathrm{~N}-\mathrm{CC} \\
23 \mathrm{~N}-1,7-8 \\
23 \mathrm{~N}-\mathrm{CC}\end{array}$ & $\begin{array}{l}\mathrm{C} \\
\mathrm{C} \\
\mathrm{C} \\
\mathrm{C} \\
\mathrm{C} \\
\mathrm{C} \\
\mathrm{F} \\
\mathrm{F} \\
\mathrm{C} \\
\mathrm{F} \\
\mathrm{A} \\
\mathrm{A}\end{array}$ & $\begin{array}{c}\mathrm{M} / \mathrm{P} \\
\mathrm{M} / \mathrm{P} \\
\mathrm{M} \\
\mathrm{P} \\
\mathrm{M} \\
\mathrm{M} / \mathrm{P} \\
\mathrm{M} \\
\mathrm{M} \\
\mathrm{M} / \mathrm{P} \\
\mathrm{P} \\
\mathrm{M} \\
\mathrm{M}\end{array}$ & $\begin{array}{l}\mathrm{F} \\
\mathrm{R} \\
\mathrm{F} \\
\text { F }\end{array}$ & $\begin{array}{l}\dot{\mathrm{F}} \\
\mathrm{R} \\
\mathrm{R}\end{array}$ & $\begin{array}{l}\text { C } \\
\text { R } \\
\text { C } \\
\text { C } \\
\text { C } \\
\text { C } \\
\text { C } \\
\text { C } \\
\text { C } \\
\text { F } \\
\text { C } \\
\text { C }\end{array}$ & $\begin{array}{l}\mathrm{R} \\
\dot{2} \\
\dot{\mathrm{F}} \\
\mathrm{F} \\
\mathrm{R} \\
\mathrm{R} \\
\mathrm{R} \\
\mathrm{R} \\
\dot{\mathrm{R}} \\
\mathrm{F}\end{array}$ & $\begin{array}{l}\mathrm{R} \\
\vdots \\
\vdots\end{array}$ & $\begin{array}{l}\dot{\vdots} \\
\vdots \\
\vdots \\
\dot{R} \\
\mathrm{R} \\
\dot{\mathrm{F}} \\
\dot{\mathrm{F}}\end{array}$ & $\begin{array}{l}\dot{\mathrm{R}} \\
\vdots \\
\vdots \\
\vdots \\
\vdots\end{array}$ & $\begin{array}{l}\mathrm{R} \\
\dot{\mathrm{F}} \\
\dot{\mathrm{C}} \\
\mathrm{R} \\
\dot{\mathrm{R}} \\
\mathrm{R} \\
\dot{\mathrm{F}} \\
\mathrm{F}\end{array}$ & $\begin{array}{ll}\vdots & \mathrm{R} \\
\mathrm{R} & \\
\mathrm{R} & \mathrm{R} \\
\vdots & \mathrm{R} \\
\vdots & \mathrm{R} \\
& ?\end{array}$ & $\begin{array}{l}\mathrm{C} \\
\mathrm{C} \\
\mathrm{C} \\
\mathrm{C} \\
\mathrm{C} \\
\mathrm{C} \\
\mathrm{C} \\
\mathrm{C} \\
\mathrm{C} \\
\mathrm{R} \\
\mathrm{R}\end{array}$ & $\begin{array}{l}\dot{C} \\
\mathrm{~F} \\
\dot{2} \\
\dot{\mathrm{R}} \\
\mathrm{R} \\
\mathrm{R} \\
\dot{ } \\
\dot{ }\end{array}$ & $\begin{array}{l}: \\
\vdots \\
\vdots \\
:\end{array}$ & $\begin{array}{l}\vdots \\
\vdots \\
\mathrm{R} \\
\vdots \\
\vdots\end{array}$ & \begin{tabular}{c|}
$\dot{2}$ \\
$\dot{\mathrm{R}}$ \\
$\dot{\mathrm{F}}$ \\
$\dot{\mathrm{F}}$ \\
$\dot{\mathrm{F}}$
\end{tabular} & : & $\begin{array}{l}\mathrm{R} \\
\vdots \\
\mathrm{R} \\
\vdots \\
\vdots \\
\mathrm{R} \\
\mathrm{R}\end{array}$ & $\begin{array}{l}\vdots \\
\mathrm{R} \\
\mathrm{R} \\
\vdots \\
\vdots\end{array}$ & $\begin{array}{l}\dot{ } \\
\dot{C} \\
\dot{\mathrm{C}} \\
\mathrm{F} \\
\dot{\mathrm{C}} \\
\dot{\mathrm{C}} \\
\dot{\mathrm{C}}\end{array}$ \\
\hline
\end{tabular}


agalum parvidentatum, occur with low-latitude forms such as Arkhangelskiella specillata, Arkhangelskiella cymbiformis, Aspidolithus parcus constrictus, Gartnerago obliquum, Quadrum trifidum, Quadrum sissinghii, and Micula murus. Reinhardtites levis, Reinhardtites sp. aff. $R$. anthophorus, Reinhardtites anthophorus, and diverse species of Prediscosphaera are also present (Table 5).

Uppermost lithologic Subunit IIB was recovered from Cores 121-758A-32X to 121-758A-38X. This subunit consists of mottled and burrowed calcareous and foraminiferal chalk that contains fragments of inoceramids and other mollusks. Calcareous nannofossils in Subunit IIB are abundant and exhibit good to moderate preservation.

The upper Maestrichtian Nephrolithus frequens Zone of Sissingh (1977) occurs in Section 121-758A-32X-1 and is characterized by the occurrence of the low-latitude form M. murus. No specimens of the high-latitude species $N$. frequens were found in this interval, suggesting that this site was tropical during the latest Maestrichtian.

The interval from Samples 121-758A-32X-3, 47-48 cm, to 121-758A-35X-5, 47-48 cm, contains mixed assemblages, making zonal assignment difficult. Reworked specimens of $A$. parcus constrictus were found with $R$. levis, Lithraphidites quadratus, and Nephrolithus corystus. Tranolithus phacelosus is very rare and inconsistent in its occurrence; it is believed to be reworked. This interval is assigned as the $R$. levis Zone (CC24) of the lower Maestrichtian based on the consistent presence of $R$. levis. Specimens of the genus Nephrolithus are generally poorly preserved.

The interval from Samples 121-758A-33X-5, 47-48 cm, to $121-758 \mathrm{~A}-40 \mathrm{X}-2,47-48 \mathrm{~cm}$, contains the assemblage of $R$. levis, $T$. phacelosus, $Q$. sissinghii, and A. parcus constrictus and lacks $R$. anthophorus. This assemblage is characteristic of the $T$. phacelosus Zone (CC23a) of late Campanian age. The upper boundary of this zone at this site was delineated by the last common occurrence of $T$. phacelosus. This stratigraphic level also corresponds to the LAD of $Q$. sissinghii, an event that Perch-Nielsen (1985) suggested is coeval with the LAD of $T$. phacelosus.

Unit III extends from the base of Subunit IIB down to Sample 121-758A-47R-CC. This unit consists of bioturbated greenish gray tuffs that contain basalt pebbles with minor beds of calcareous chalk and shell fragments. Calcareous nannofossils in Unit III are common to rare, exhibiting moderate to poor preservation. Unit IV, the lowermost Cretaceous sediment at Site 758, is dominated by gray tuffs with minor interbeds of ashy, calcareous chalk and partially indurated ash beds. It also contains some pyrite in burrows, rounded basalt pebbles, and shell fragments. The sedimentary structures include some sharp scoured contacts, microfractures, and soft-sediment deformation structures. The calcareous nannofossils in this unit also exhibit moderate to poor preservation but are very rare or absent in some samples in the lower part of the section.

The calcareous nannofossil assemblages in the interval from Sample 121-758A-40X-CC through Core 121-758A-57R (total depth) are uniform in nature and composition. The assemblage is characterized by the occurrence of $R$. anthophorus, $R$. levis, $Q$. trifidum, $Q$. sissinghii, and Eiffellithus eximius. This indicates the upper $Q$. trifidum Zone (CC22c) of the upper Campanian. The Maestrichtian/Campanian boundary is placed in Sample 121$758 \mathrm{~A}-41 \mathrm{X}-5,46-47 \mathrm{~cm}$, at the LAD of E. eximius. The presence of the Quadrum spp. and the absence of austral forms indicate that conditions at this site were temperate to tropical during the late Campanian to early Maestrichtian.

\section{SUMMARY AND CONCLUSIONS}

The Cretaceous calcareous nannofossils recovered from the sites drilled during Leg 121 range from Turonian to late
Maestrichtian, as summarized in Figure 4. Micrographs of diagnostic species are presented in Plates 1-8.

Maestrichtian calcareous nannofossil assemblages were recovered from Sites 752 and 754 on Broken Ridge and Site 758 on Ninetyeast Ridge. The quality of the upper Maestrichtian calcareous nannofossil assemblages from the Broken Ridge sites is generally moderate to poor. The assemblages are characterized by high-latitude species. The upper Campanian through Maestrichtian calcareous nannofossil assemblages recovered from Sites 752 and 754 (Broken Ridge) are strongly austral in character. They are quite similar to the assemblages recovered from the Falkland Plateau (Legs 36 and 71), the Weddell sea (Leg 113), and the central Kerguelen Plateau (Leg 120). The Nephrolithus frequens Zone of Sissingh (1977) can not be applied at the uppermost Maestrichtian section at Broken Ridge because of the overlapping ranges of $N$. frequens and Reinhardtites levis. At Site 758 (Ninetyeast Ridge) the upper Maestrichtian assemblages are moderately to well preserved. The assemblage contains some high-latitude forms, but the distinctive lower latitude taxon Micula murus is also present.

The early Maestrichtian assemblages are mostly very poor at the Broken Ridge sites. At Site 754, barren samples were found alternating with intervals containing very few, scattered species in the very thick limestone-chert section. SEM work suggests that the lowermost sediment at this site is also Maestrichtian in age. At Ninetyeast Ridge (Site 758), many reworked specimens were found, making the biostratigraphic assignment difficult.

An upper Campanian section was recovered from Site 758. The low-latitude taxa Quadrum sissinghii and Quadrum trifidum are well preserved. In addition, several high-latitude species were found in these assemblages, indicating a mixing of southern and temperate water masses.

The Turonian to lowermost Campanian were recovered only from Site 755 on Broken Ridge. For the most part, the preservation is very poor. Barren samples were found in the lower part of the section. The rapid ash-rich sedimentation at this time was not favorable for the preservation of calcareous nannofossils.

\section{TAXONOMIC NOTES}

Genus Eprolithus Stover (1966)

Eprolithus sp. 1

(PI. 8, Figs. 4, 5)

Remarks. Perch-Nielsen (1985, figs. 56.17 and 56.18) considered this form intermediate between Eprolithus floralis (Stradner, 1962) Stover (1966) and the first representative of the genus Quadrum (i.e., her Quadrum sp.). The forms illustrated here appear to be identical with those of Perch-Nielsen (1985). This taxon differs from E. floralis (s.s.) in having an irregular shape with eight to nine wall elements.

\section{Eprolithus sp. 2 \\ (Pl. 8, Figs. 7, 8)}

Remarks. This form is identical to Eprolithus sp. 2 of Perch-Nielsen $(1979,1985)$; I have followed her nomenclature designation. This form differs from E. floralis (s.s.) in having eight acute wall elements with a moderately open central area. Perch-Nielsen (1979) suggested that this form could represent the ancestor of the Late Cretaceous genus Lithastrinus.

Genus Reinhardtites Perch-Nielsen (1968)

Reinhardtites sp. aff. $R$. anthophorus (Deflandre, 1959) Perch-Nielsen (1968)

$$
\text { (Pl. 4, Fig. 4) }
$$

Remarks. Sissingh (1977) considered this form to be transitional between $R$. anthophorus and $R$. levis Prins and Sissingh (1977 in Sissingh, 1977). It is characterized by a moderately large central opening surrounded by a wide plate-lining at both sides of the central bridge structure. It differs from $R$. anthophorus in having narrower central openings and in the absence of the widened inverted cone structure in its stem. It differs from $R$. levis in having wider central openings. 


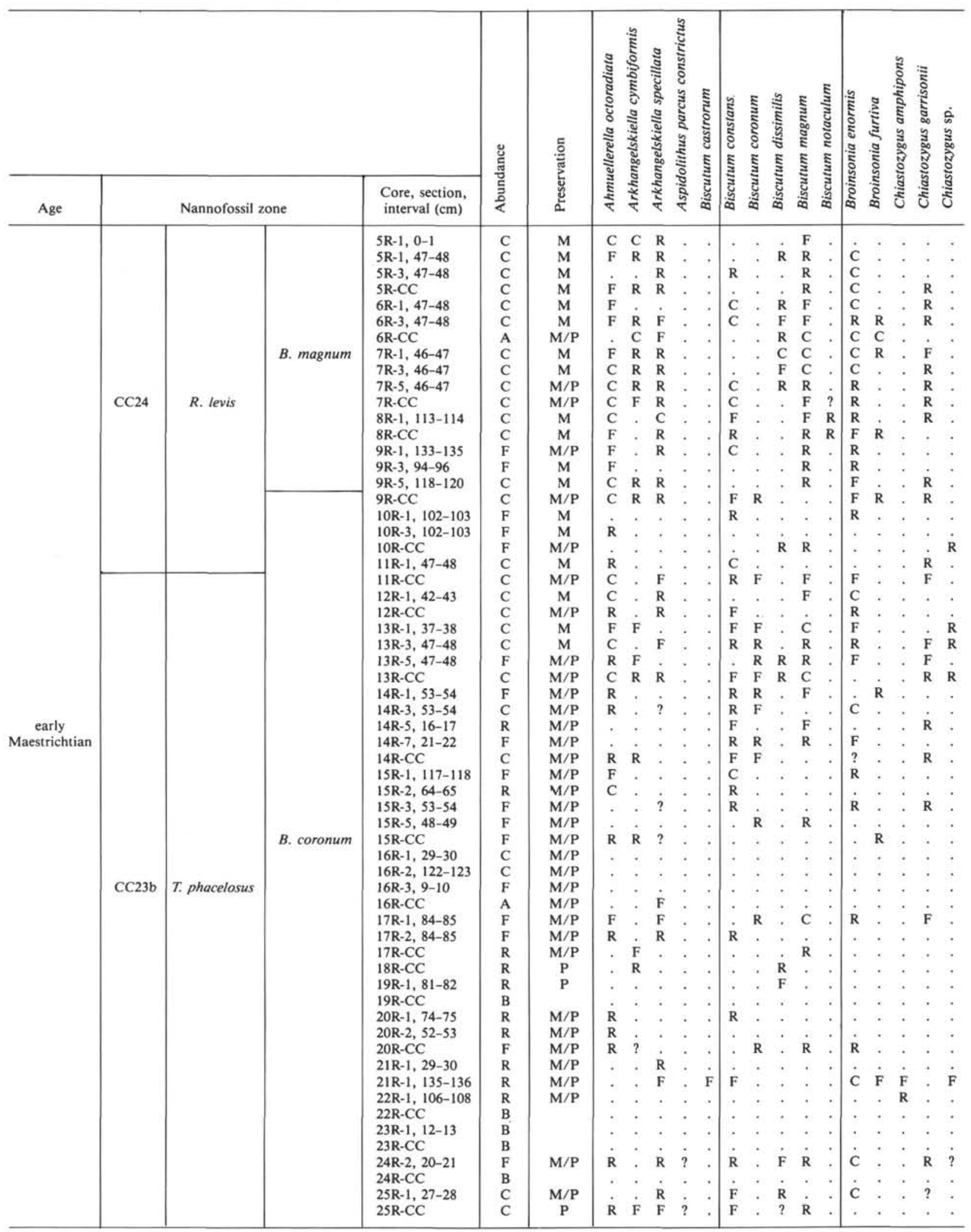

Note: Preservation: $\mathrm{G}=$ good, $\mathrm{M}=$ moderate, $\mathrm{P}=$ poor. Abundance: $\mathrm{A}=$ abundant, $\mathrm{C}=$ common, $\mathrm{F}=$ few, $\mathrm{R}=$ rare, ? $=$ questionably present, $\mathrm{B}=$ barren. 
Table 3 (continued).

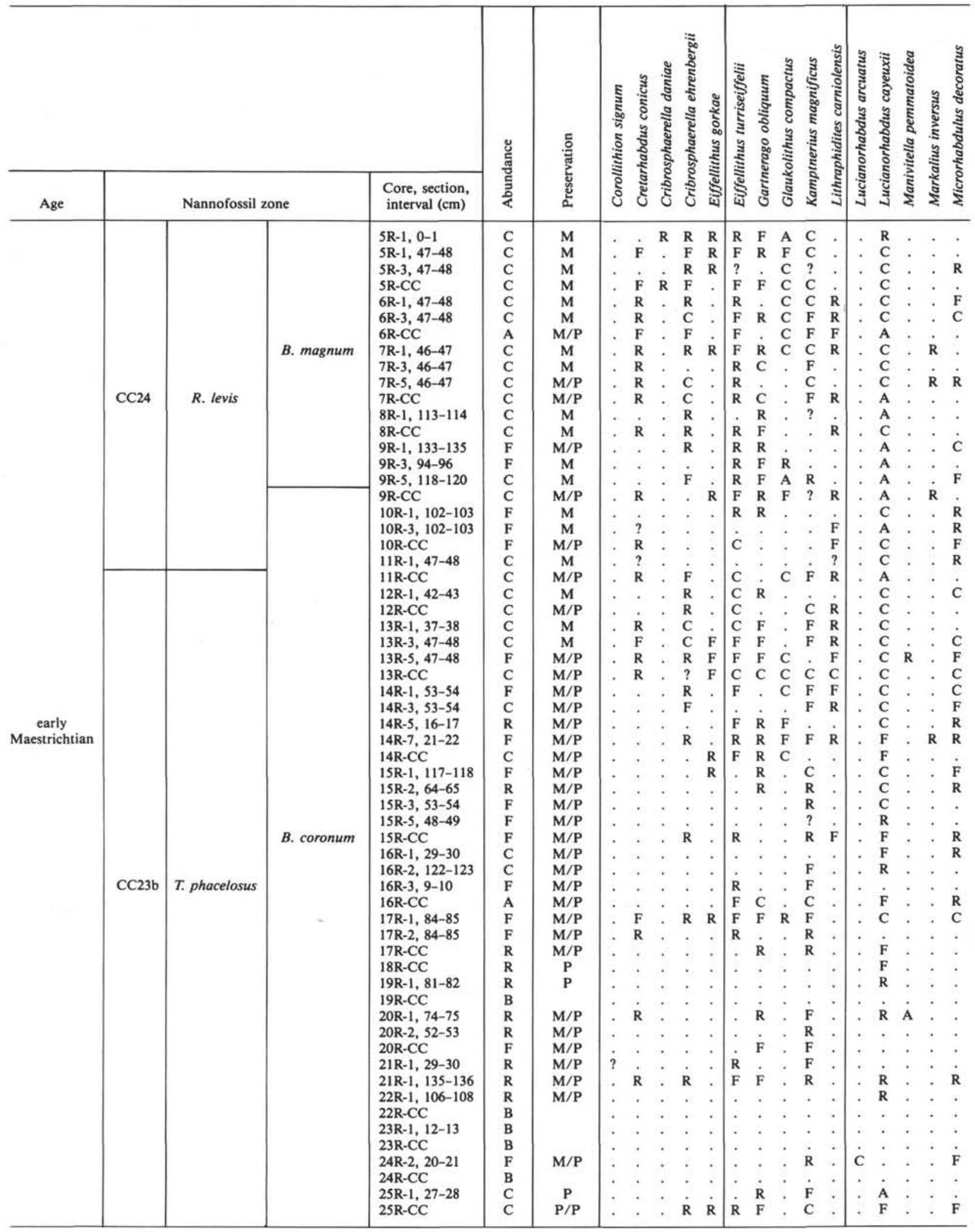


Table 3 (continued).

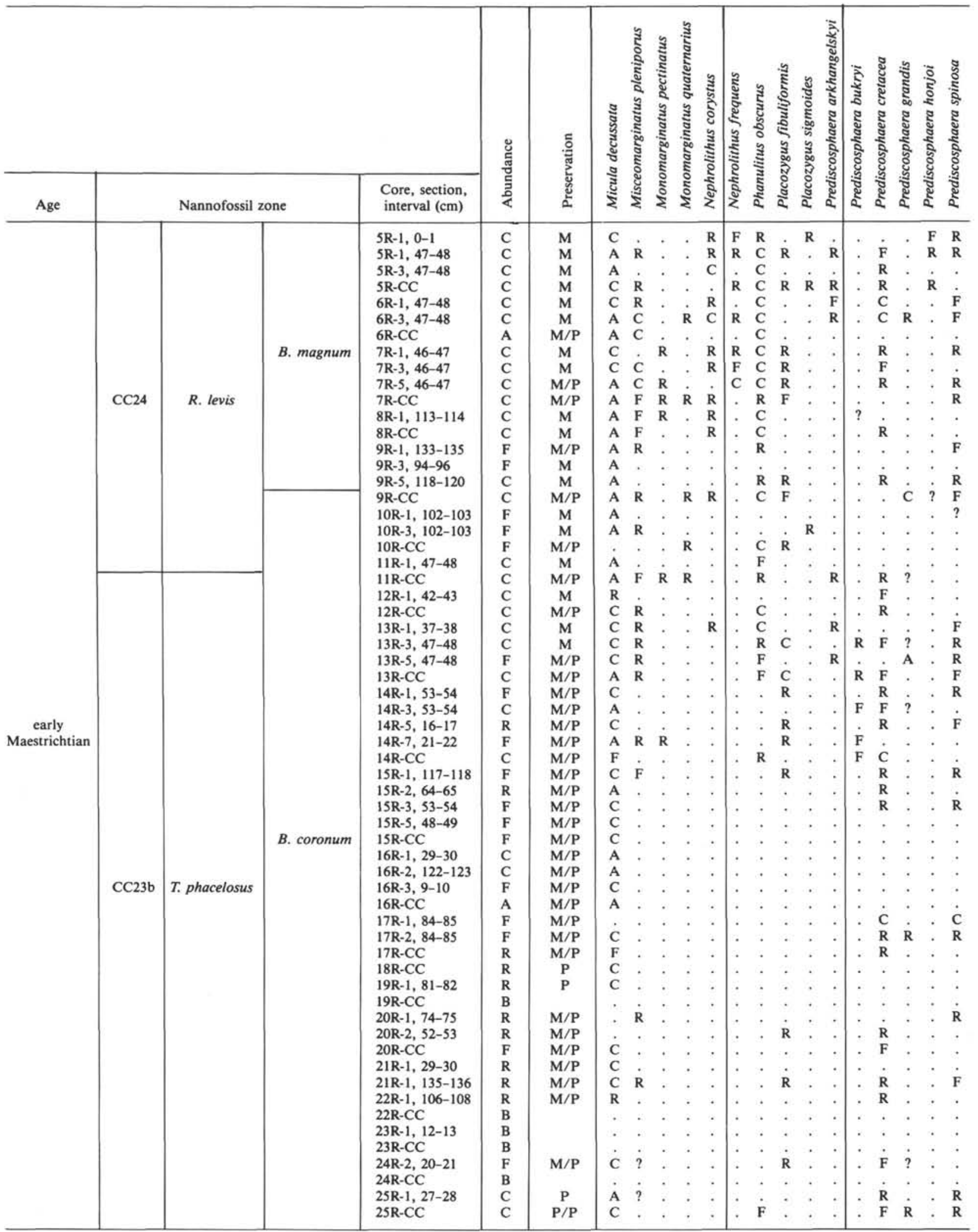




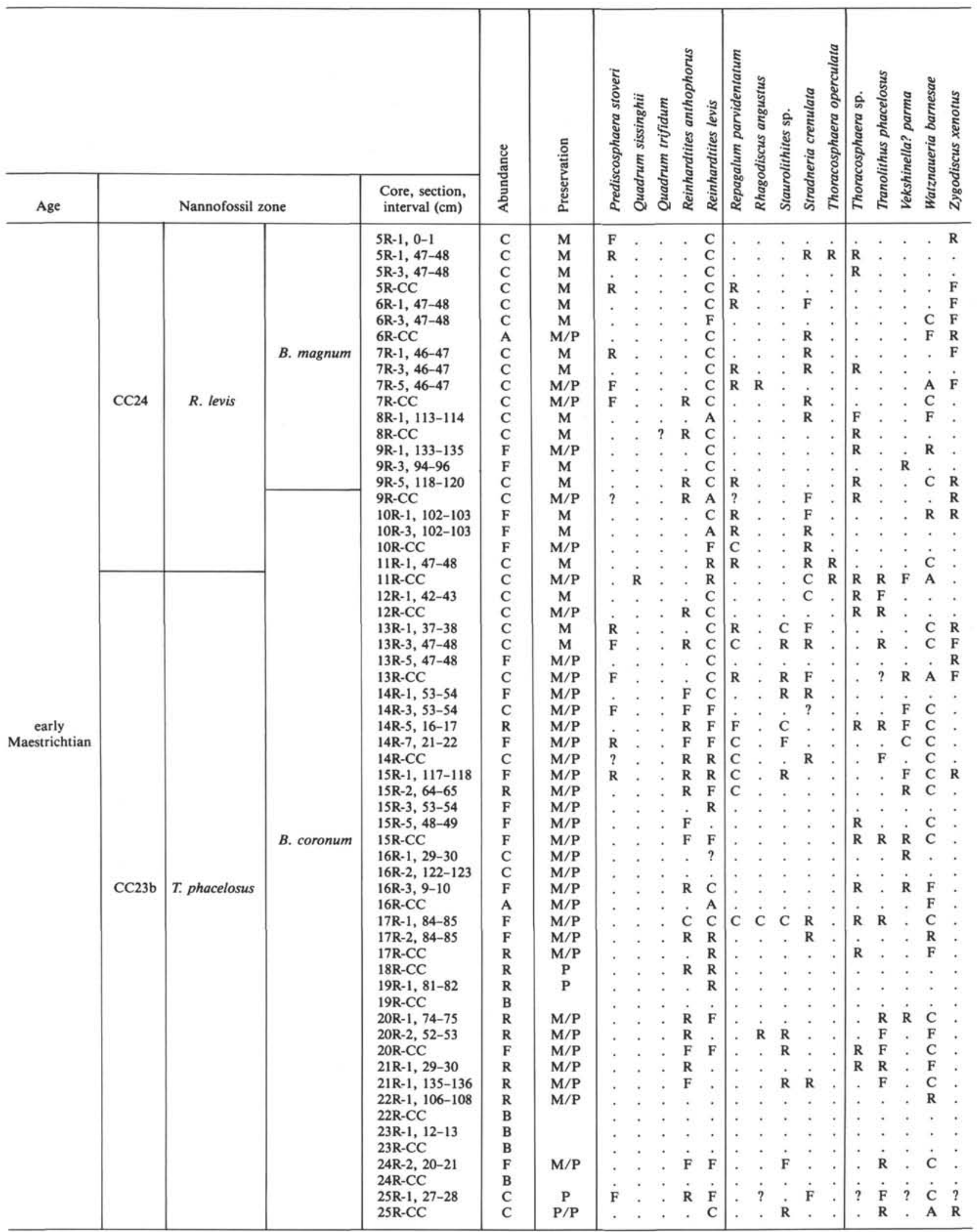


Table 4. Turonian-lower Campanian calcareous nannofossils, Hole 755A.

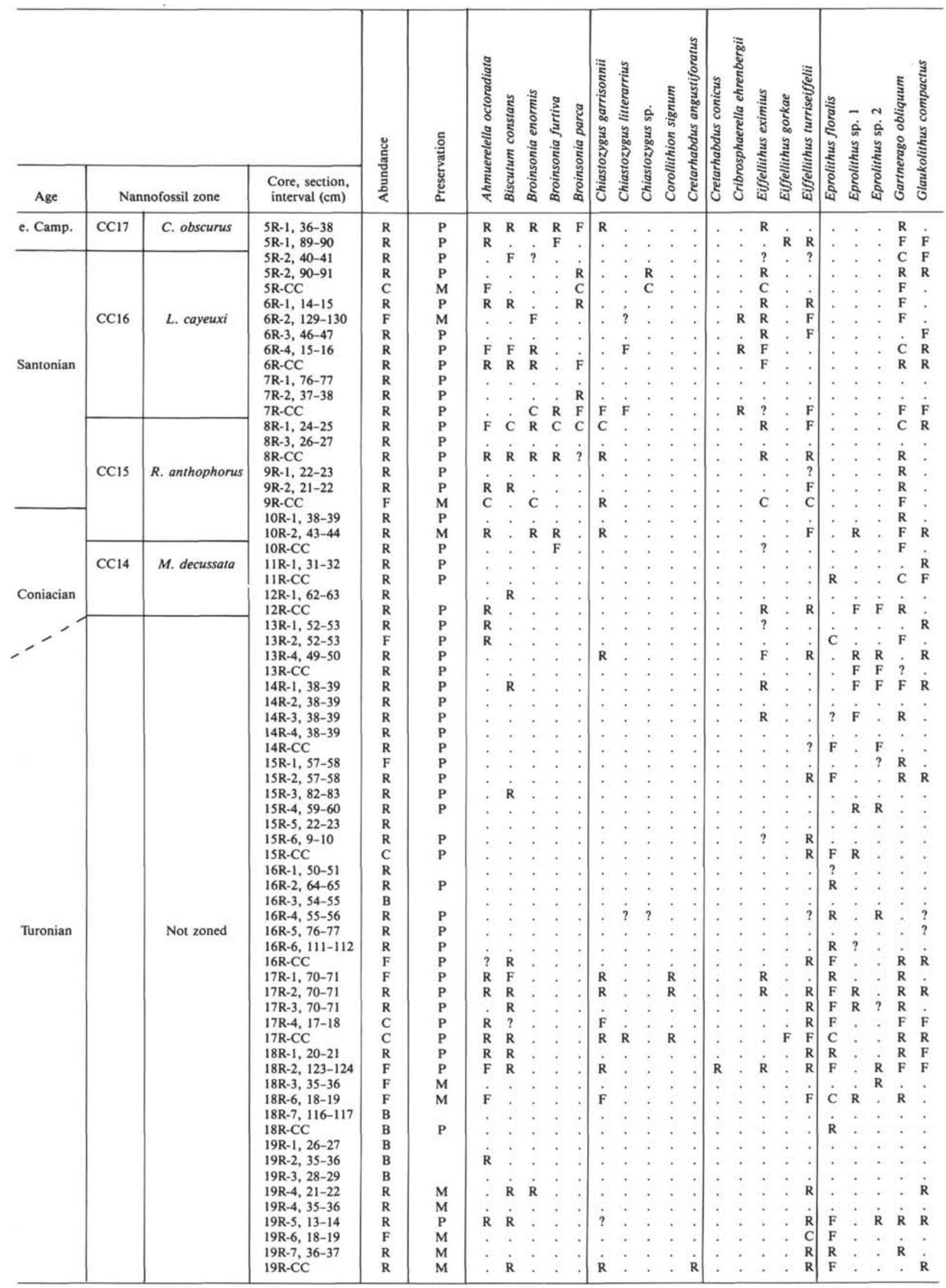

Note: Preservation: $\mathrm{G}=$ good, $\mathrm{M}=$ moderate, $\mathrm{P}=$ poor. Abundance: $\mathrm{A}=$ abundant, $\mathrm{C}=$ common, $\mathrm{F}=\mathrm{few}, \mathrm{R}=$ rare, ? $=$ questionably present, $\mathrm{B}=$ barren, . = not present. 


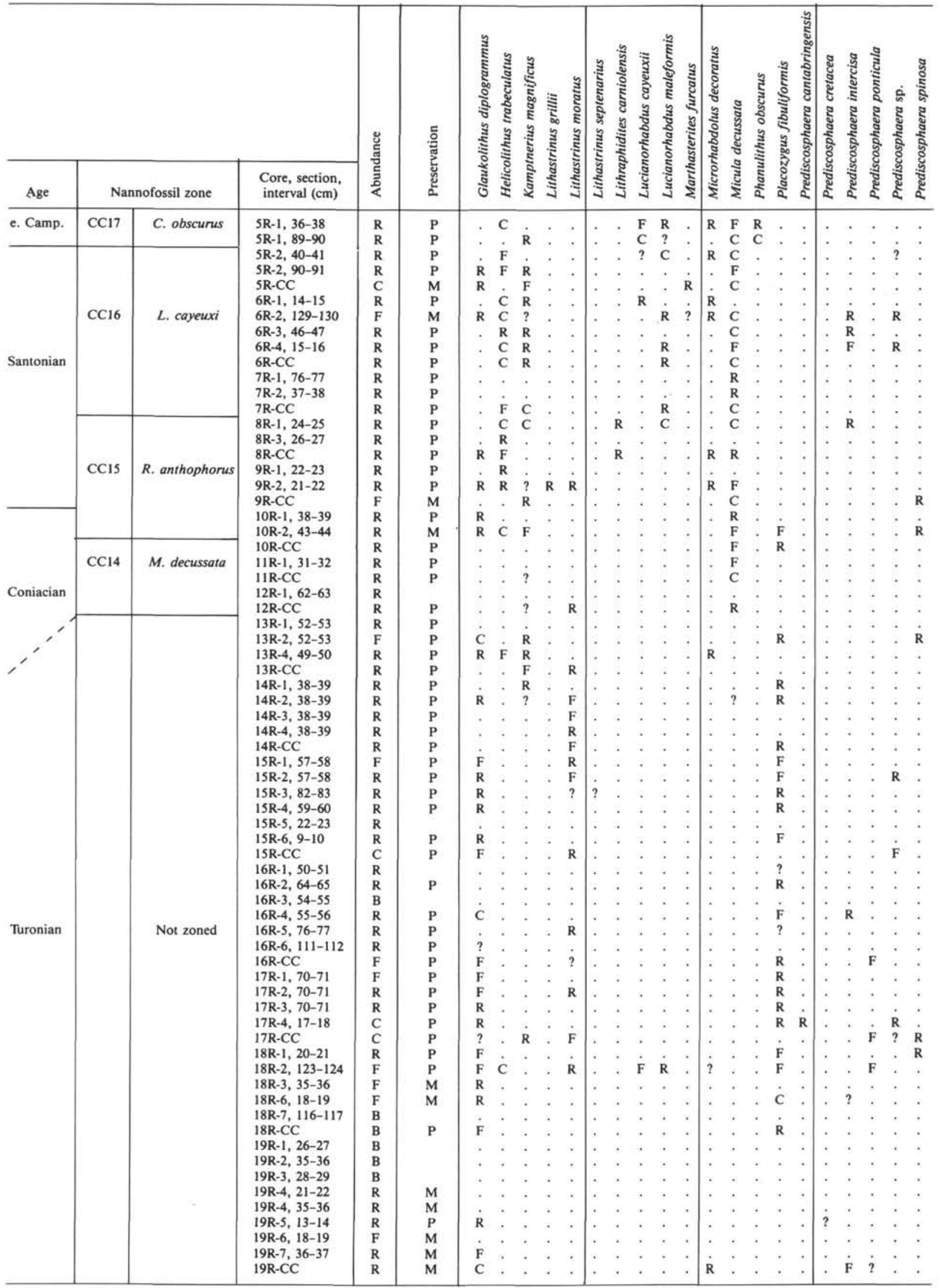


Table 4 (continued).

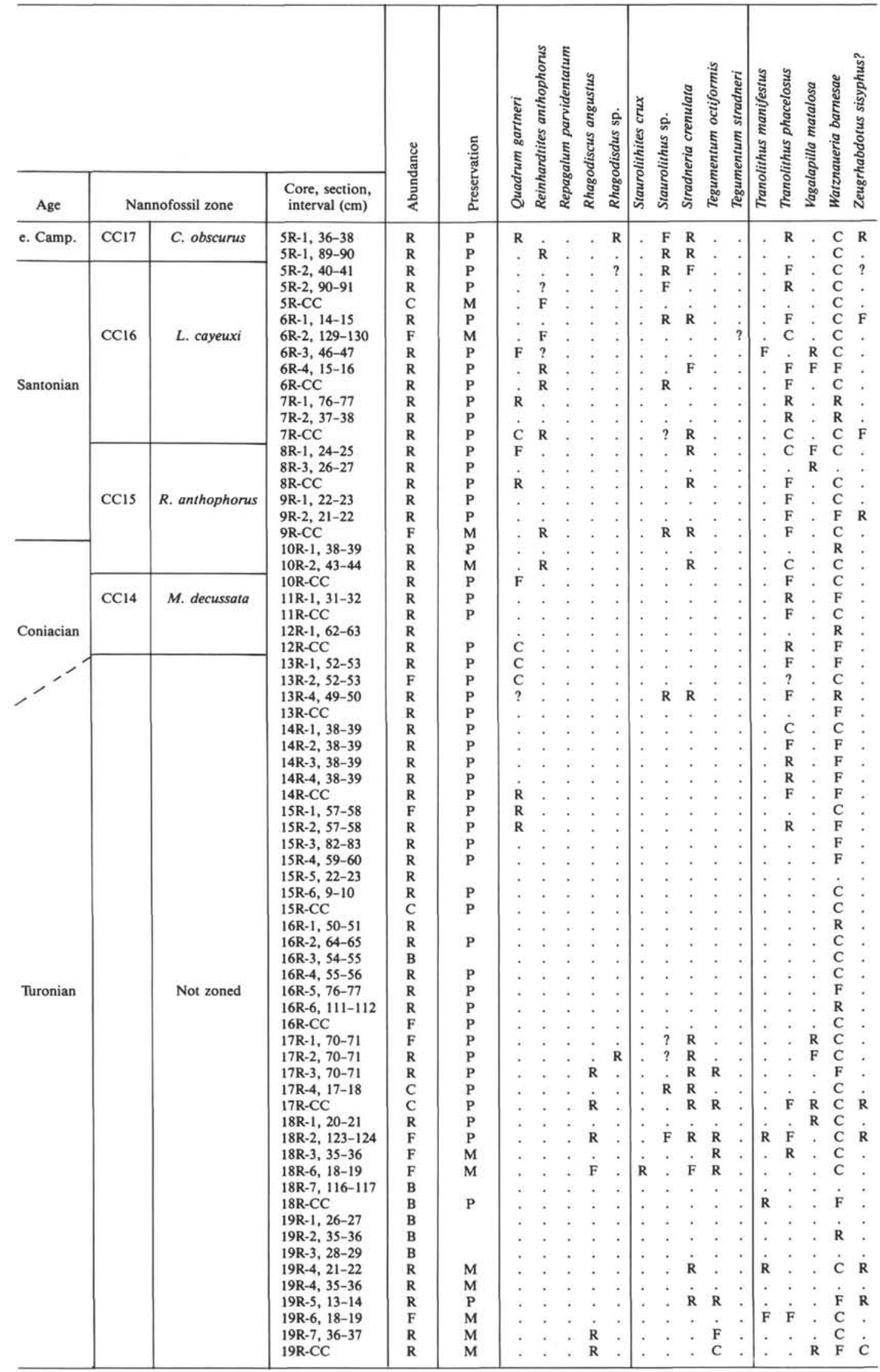




\section{ACKNOWLEDGMENTS}

I thank the Ocean Drilling Program and the U.S. Scientific Advisory Committee (USSAC) for financial support in completing this project. Support from the Department of Geology, University of Nebraska-Lincoln, is also gratefully acknowledged. Special thanks and deep appreciation is expressed to Dr. David $\mathrm{K}$. Watkins for his help, suggestions, and encouragement.

\section{REFERENCES}

Hay, W. W., 1970. Calcareous nannofossils from cores recovered on DSDP Leg 4. In Bader, R. G., Gerard, R. D., et al., Init. Repts. DSDP, 4: Washington (U.S. Govt. Printing Office), 455-501.

Kent, D. V., and Gradstein, F. M., 1985. A Cretaceous and Jurassic geochronology. Geol. Soc. Am. Bull., 96:1419-1427.

Loeblich, A. R., and Tappan, H., 1966. Annotated index and bibliography of the calcareous nannoplankton. Phycologia, 5:81-215.

1968. Annotated index and bibliography of the calcareous nannoplankton II. J. Paleontol., 42:584-598.

1969. Annotated index and bibliography of the calcareous nannoplankton III. J. Paleontol., 43:568-588.

1970a. Annotated index and bibliography of the calcareous nannoplankton IV. J. Paleontol., 44:558-574.

1970b. Annotated index and bibliography of the calcareous nannoplankton V. Phycologia, 9:157-174.

1971. Annotated index and bibliography of the calcareous nannoplankton VI. Phycologia, 10:315-339.

1973. Annotated index and bibliography of the calcareous nannoplankton VII. J. Paleontol., 47:715-759.

Luyendyk, B. P., 1977. Deep sea drilling on the Ninetyeast Ridge: synthesis and a tectonic model. In Heirtzler, J. R., Bolli, H. M., Davies, T. A., Saunders, J. B., and Sclater, J. G. (Eds.), Indian Ocean Geology and Biostratigraphy: Washington (Am. Geophys. Union), 165-187.

Luyendyk, B. P., and Rennick, W., 1977. Tectonic history of aseismic ridges in the eastern Indian Ocean. Geol. Soc. Am. Bull., 88:13471356.

Peirce, J., Weissel, J., et al., 1989. Proc. ODP, Init. Repts., 121: College Station, TX (Ocean Drilling Program).

Peirce, J. W., 1978. The northward motion of India since the Late Cretaceous. Geophys. J. R. Astron. Soc., 52:277-311.

Perch-Nielsen, K., 1979. Calcareous nannofossils from the Cretaceous between the North Sea and the Mediterranean. In Wiedmann, J. (Ed.), Aspekte der Kreide Europeas. Int. Union Geol. Sci., Ser. A, 6:223272.

1985. Mesozoic calcareous nannofossils. In Bolli, H., Saunders, J. B., and Perch-Nielsen, K. (Eds.), Plankton Stratigraphy: Cambridge (Cambridge Univ. Press), 329-426.

Pospichal, J. J., 1989. Southern high latitude K/T boundary calcareous nannofossils from ODP Sites 690 and 752. INA Newsl., 11:90-91.

Pospichal, J. J., and Wise, S. W., Jr., 1990. Maestrichtian calcareous nannofossil biostratigraphy of Maud Rise ODP Leg 113 Sites 689 and 690, Weddell Sea. In Barker, P. F., Kennett, J. P., et al., Proc. ODP, Sci. Results, 113: College Station, TX (Ocean Drilling Program), 465-487.

Roth, P. H., 1978. Cretaceous nannoplankton biostratigraphy and oceanography of the northwestern Atlantic Ocean. In Benson, W. E., Sheridan, R. E., et al., Init. Repts. DSDP, 44: Washington (U.S. Govt. Printing Office), 731-760.

Sissingh, W., 1977. Biostratigraphy of Cretaceous calcareous nannoplankton. Geol. Mijnbouw, 56:37-65.

1978. Microfossil biostratigraphy and stage stratotypes of the Cretaceous. Geol. Mijnbouw, 57:433-400.

Steinmetz, J. C., 1984a. Bibliography and taxa of calcareous nannoplankton-III. INA Newsl., 6:6-37.

1984b. Bibliography and taxa of calcareous nannoplanktonIV. INA Newsl., 6:55-81.

1985a. Bibliography and taxa of calcareous nannoplankton-V. INA Newsl., 7:5-28.

1985b. Bibliography and taxa of calcareous nannoplanktonVI. INA Newsl., 7:122-145.

, 1986. Bibliography and taxa of calcareous nannoplankton- 1987a. Bibliography and taxa of calcareous nannoplanktonIX. INA Newsl., 9:6-29.

1987b. Bibliography and taxa of calcareous nannoplankton-X. INA Newsl., 10:81-109.

1988a. Bibliography and taxa of calcareous nannoplanktonXI. INA Newsl., 10:7-28.

1988b. Bibliography and taxa of calcareous nannoplanktonXII. INA Newsl., 10:60-88.

1989. Bibliography and taxa of calcareous nannoplanktonXIII. INA Newsl., 11:6-23.

Stradner, H., 1964. New contribution to Mesozoic stratigraphy by means of nannofossils. In Haq, B. U. (Ed.), Nannofossil Biostratigraphy: Stroudsburg, PA (Hutchinson Ross).

Thierstein, H. R., 1976. Mesozoic calcareous nannoplankton biostratigraphy of marine sediments. Mar. Micropaleontol., 1:325-362.

1981. Late Cretaceous nannoplankton and the change at the Cretaceous-Tertiary boundary. In Warme, J. E., Douglas, R. G., Winterer, E. L. (Eds.), The Deep Sea Drilling Project: A Decade of Progress: Soc. Econ. Paleontol. Mineral., Spec. Publ., 32:355-394.

van Heck, S. E., 1979a. Bibliography and taxa of calcareous nannoplankton. INA Newsl., 1:AB1-B27.

1979b. Bibliography and taxa of calcareous nannoplankton. INA Newsl., 1:ABV1-B42.

1980a. Bibliography and taxa of calcareous nannoplankton. INA Newsl., 2:5-34.

1980b. Bibliography and taxa of calcareous nannoplankton. INA

Newsl., 2:43-81.

1981 a. Bibliography and taxa of calcareous nannoplankton. INA Newsl., 3:4-41.

1981b. Bibliography and taxa of calcareous nannoplankton. INA Newsl., 3:51-86.

1982a. Bibliography and taxa of calcareous nannoplankton. INA Newsl., 4:7-50.

1982b. Bibliography and taxa of calcareous nannoplankton. INA Newsl., 4:65-96.

1983. Bibliography and taxa of calcareous nannoplankton. INA Newsl., 5:4-13.

Watkins, D. K., in press. Upper Cretaceous nannofossils from ODP Leg 120, Kerguelen Plateau, Southern Ocean. In Schlich, R., Wise, S. W., Jr., et al., Proc. ODP, Sci. Results, 120: College Station, TX (Ocean Drilling Program).

Watkins, D. K., and Bowdler, J. L., 1984. Cretaceous calcareous nannofossils from DSDP Leg 77, southeast Gulf of Mexico. In Buffler, R. T., Schlager, W., et al., Init. Repts. DSDP, 77: Washington (U.S. Govt. Printing Office), 649-674.

Watkins, D. K., Wise, S. W., Jr., and Pospichal, J. J., 1989. TuronianMaastrichtian nannofossil biostratigraphy and paleoceanography of the Southern Ocean. INA Newsl., 11:106.

Wind, F. H., 1979a. Late Campanian and Maestrichtian calcareous nannoplankton biogeography and high-latitude biostratigraphy [Ph.D. dissert.]. Florida State Univ., Tallahassee.

1979b. Maestrichtian-Campanian nannofloral provinces of the southern Atlantic and Indian Oceans. In Talwani, M., Hay, W., and Ryan, W.B.F. (Eds.), Deep Sea Drilling Results in the Atlantic Ocean: Continental Margins and Paleoenvironment: Am. Geophys. Union, Maurice Ewing Ser., 3:123-137.

Wind, F. H., and Wise, S. W., 1983. Correlation of Upper CampanianLower Maestrichtian calcareous nannofossil assemblages in drill and lower piston cores from the Falkland Plateau, southwest Atlantic Ocean. In Ludwig, W. J., Krasheninnikov, V. A., et al., Init. Repts. DSDP, 71: Washington (U.S. Govt. Printing Office), 551-563.

Wise, S. W., Jr., 1983. Mesozoic and Cenozoic calcareous nannofossils recovered by Deep Sea Drilling Project Leg 71 in the Falkland Plateau region, Southwest Atlantic Ocean. In Ludwig, W. J., Krasheninnikov, V. A., et al., Init. Repts. DSDP, 71: Washington (U.S. Govt. Printing Office), 481-550.

1988. Mesozoic-Cenozoic history of calcareous nannofossils in the region of the Southern Ocean. Palaeogeogr., Palaeoclimatol., Palaeoecol., 67:157-179.

Wise, S. W., Jr., and Wind, F. H., 1977. Mesozoic and Cenozoic calcareous nannofossils recovered by DSDP Leg 36 drilling on the Falkland Plateau, southwest Atlantic sector of the Southern Ocean. In Barker, P., Dalziel, I.W.D., et al., Init. Repts. DSDP, 36: Washington (U.S. Govt. Printing Office), 269-492. 


\section{P. RESIWATI}

Worsley, T., and Martini, E., 1970. Late Maestrichtian nannoplankton provinces. Nature, 225:1242-1243.

\section{Date of initial receipt: 19 March 1990}

Date of acceptance: 9 November 1990

Ms 121B-141

\section{APPENDIX}

Species Considered in this Report in Alphabetical Order of Generic Epithets

Bibliographic references for these taxa are found in Loeblich and Tappan $(1966,1968,1969,1970 a, 1970 b, 1971,1973)$, van Heck (1979a, 1979b, 1980a, 1980b, 1981a, 1981b, 1982a, 1982b, 1983), and Steinmetz (1984a, 1984b, 1985a, 1985b, 1986, 1987a, 1987b, 1988a, 1988b, 1989). Any taxa not cited therein are cited in the references of this paper.

Ahmuellerella octoradiata (Gorka) Reinhardt (1964)

Arkhangelskiella cymbiformis Vekshina, 1959

Arkhangelskiella specillata Vekshina, 1959

Aspidolithus parcus constrictus (Hattner et al., 1980)

Aspidolithus parcus expansus (Wise and Watkins, 1983) Perch-Nielsen 1984

Aspidolithus parcus parcus (Stradner, 1963) Noel (1969)

Biscutum castrorum Black, 1959

Biscutum constans (Gorka, 1957)

Biscutum coronum Wind and Wise in Wise and Wind, 1977

Biscutum dissimilis Wind and Wise in Wise and Wind, 1977

Biscutum magnum Wind and Wise in Wise and Wind, 1977

Biscutum notaculum Wind and Wise in Wise and Wind, 1977

Braarudosphaera bigelowii (Grun and Braarud, 1935) Deflandre (1947)

Broinsonia enormis (Shumenko, 1968) Manivit, 1971

Broinsonia furtiva Bukry (1969)

Calculites obscurus (Deflandre, 1959) Prins and Sissingh in Sissingh, 1977

Calculites ovalis (Stradner, 1963) Prins and Sissingh in Sissingh, 1977

Ceratolithoides aculeus (Stradner, 1961) Prins and Sissingh in Sissingh, 1977

Chiastozygus amphipons (Bramlette and Martini, 1964) Gartner, 1968

Chiastozygus garrisonii Bukry, 1969 in Wise and Wind, 1977

Chiastozygus litterarius (Gorka, 1957) Manivit, 1971

Corollithion signum Stradner, 1968

Cretarhabdus angustiforatus (Black, 1971) Bukry, 1973

Cretarhabdus conicus Bramlette and Martini, 1964

Cretarhabdus loriei Gartner, 1968

Cribrosphaerella daniae Perch-Nielsen, 1973

Cribrosphaerella ehrenbergii (Arkhangelsky, 1912) Deflandre, 1952

Eiffellithus eximius (Stover, 1966) Perch-Nielsen, 1968

Eiffellithus gorkae Reinhardt, 1965

Eiffellithus turriseiffelii (Deflandre and Fert) Reinhardt, 1965

Eprolithus floralis (Stradner, 1962) Stover, 1966

Gartnerago obliquum (Stradner) Reinhardt, 1970

Glaukolithus compactus (Bukry, 1969) Perch-Nielsen (1984a)

Glaukolithus diplogrammus (Deflandre in Deflandre and Fert, 1954) Reinhardt (1964)

Helicolithus trabeculatus (Gorka, 1957) Verbeek, 1977

Kamptnerius magnificus Deflandre, 1959

Lapideacassis mariae Black, emend. Wind and Wise in Wise and Wind, 1977

Lithastrinus grillii Stradner, 1962
Lithastrinus moratus Stover (1966)

Lithastrinus septenarius Forchheimer (1972)

Lithraphidites carniolensis Deflandre, 1963

Lithraphidites quadratus Roth, 1978

Lithraphidites prequadratus, Bramlette and Martini, 1964

Lucianorhabdus cayeuxii Deflandre, 1959

Lucianorhabdus maleformis Reinhardt, 1966

Manivitella pemmatoidea (Deflandre in Manivit, 1965) Thierstein (1971)

Markalius inversus (Deflandre in Deflandre and Fert, 1954) Bramlette and Martini, 1964

Marthasterites furcatus (Deflandre) Deflandre, 1959

Microrhabdulus decoratus Deflandre, 1959

Micula decussata Vekshina, 1959

Micula murus (Martini, 1961) Bukry (1973)

Misceomarginatus pleniporus Wind and Wise in Wise and Wind, 1977

Monomarginatus pectinatus Wind and Wise in Wise and Wind, 1977

Monomarginatus quaternarius Wind and Wise in Wise and Wind, 1977

Nephrolithus corystus Wind, 1983

Nephrolithus frequens Gorka, 1959

Placozygus fibuliformis (Reinhardt, 1964) Hoffmann (1970b)

Placozygus sigmoides (Bramlette and Sullivan, 1961) Romein (1979)

Prediscosphaera arkhangelskyi (Reinhardt, 1965) Perch-Nielsen (1984a)

Prediscosphaera bukryi Perch-Nielsen (1973)

Prediscosphaera cretacea (Arkhangelsky, 1912) Gartner, 1968

Prediscosphaera grandis Perch-Nielsen, 1979

Prediscosphaera honjoi Bukry, 1969

Prediscosphaera intercisa (Deflandre in Deflandre and Fert, 1954) Shumenko, 1976

Prediscosphaera spinosa (Bramlette and Martini) Gartner, 1968

Prediscosphaera stoveri (Perch-Nielsen) Shafik and Stradner, 1971

Quadrum gartneri Prins and Perch-Nielsen in Manivit et al., (1977)

Quadrum sissinghii Perch-Nielsen, 1984

Quadrum trifidum (Stradner in Stradner and Papp, 1961) Prins and PerchNielsen, 1984

Reinhardtites anthophorus (Deflandre, 1959) Perch-Nielsen (1968)

Reinhardtites sp. aff. $R$. anthophorus (Deflandre) Perch-Nielsen, 1968

Reinhardtites levis Prins and Sissingh, 1977

Repagalum parvidentatum (Deflandre and Fert, 1954) Forchheimer (1972)

Rhagodiscus angustus (Stradner, 1963) Reinhardt (1971)

Scampanella cornuta Forchheimer and Stradner, 1964

Staurolithus sp., Crux, 1989

Stradneria crenulata (Bramlette and Martini) Noel, 1970a

Tegumentum stradneri Thierstein in Roth and Thierstein (1972)

Tegumentum octiformis (Kothe, 1981)

Thoracosphaera operculata Bramlette and Martini, 1974

Tranolithus exiguus Stover, 1977

Tranolithus gabalus Stover, 1976

Tranolithus manifestus Stover (1966)

Tranolithus phacelosus Stover, 1966

Vagalapilla matalosa (Stover, 1966) Thierstein, 1973

Vekshinella? parma Wind and Wise, 1977

Watznaueria barnesae (Black) Perch-Nielsen, 1968

Zeugrhabdotus embergeri (Noel, 1959) Perch-Nielsen (1984a)

Zeugrhabdotus sysiphus (Gartner, 1968)

Zygodiscus xenotus (Stover) Rissatti, 1973 


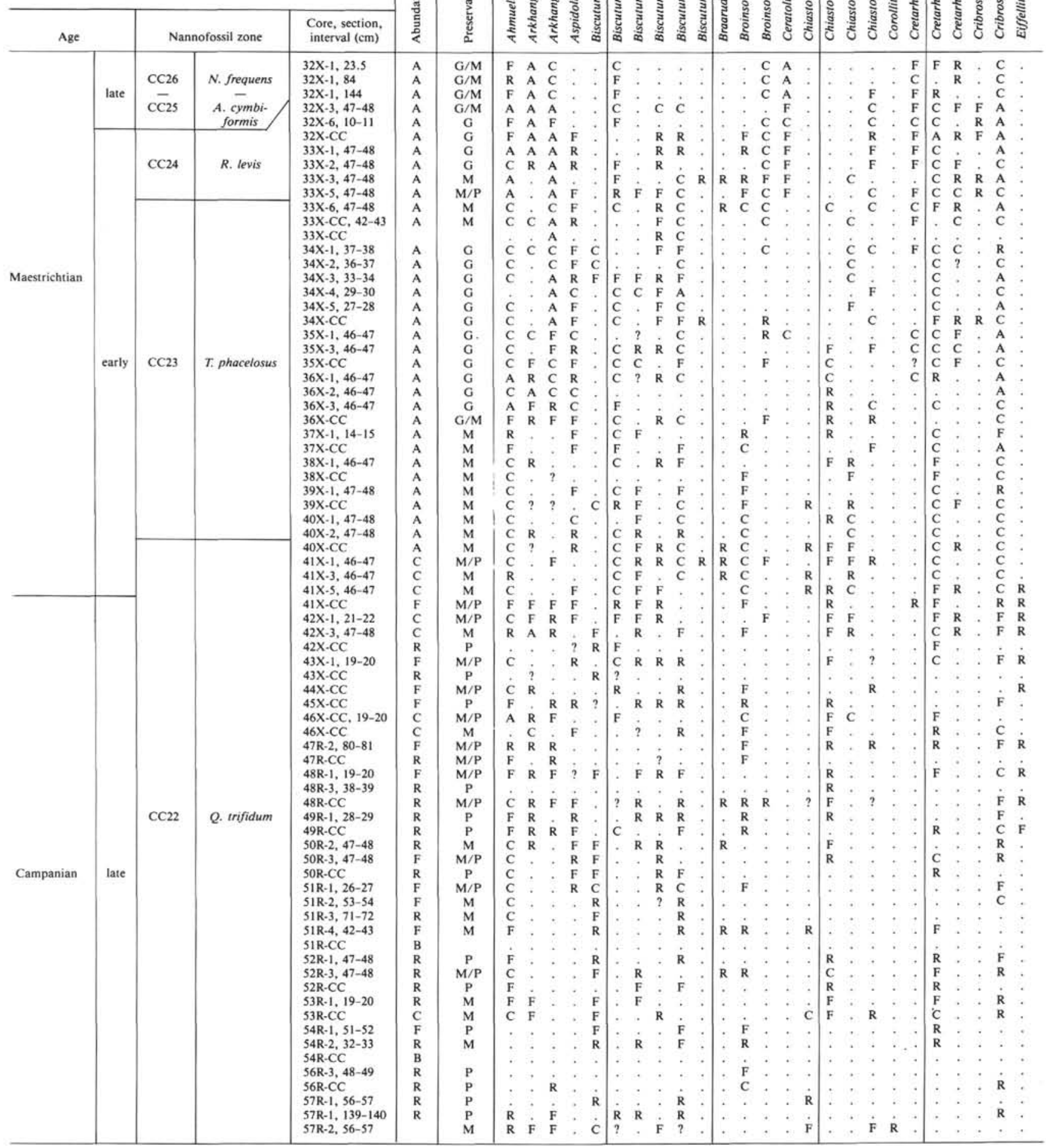

Note: Preservation: $\mathrm{G}=\operatorname{good}, \mathrm{M}=$ moderate, $\mathrm{P}=$ poor. Abundance: $\mathrm{A}=$ abundant, $\mathrm{C}=$ common, $\mathrm{F}=$ few, $\mathrm{R}=$ rare, ? $=$ questionably present, $\mathrm{B}=$ barren,$=$ not present. 


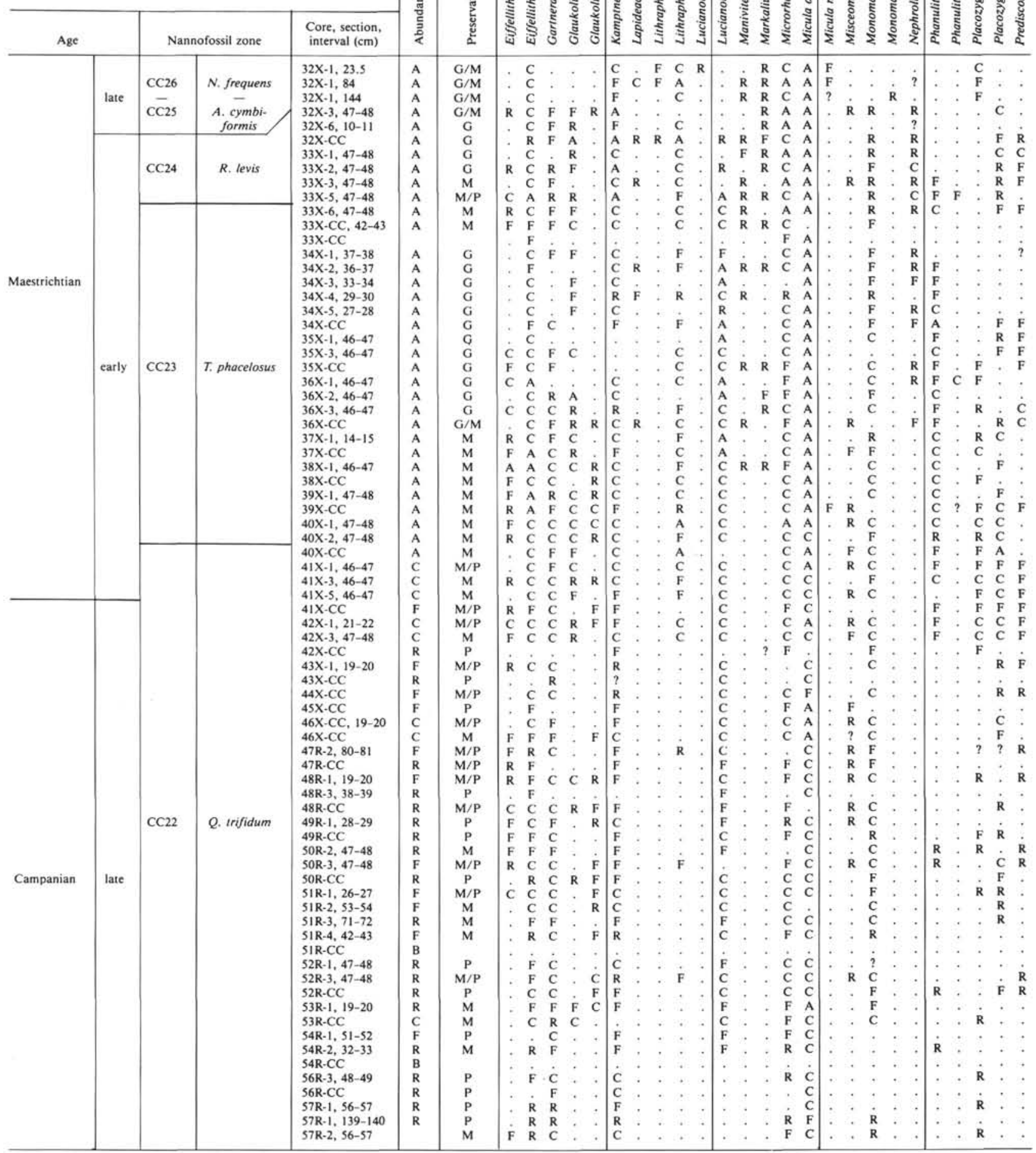




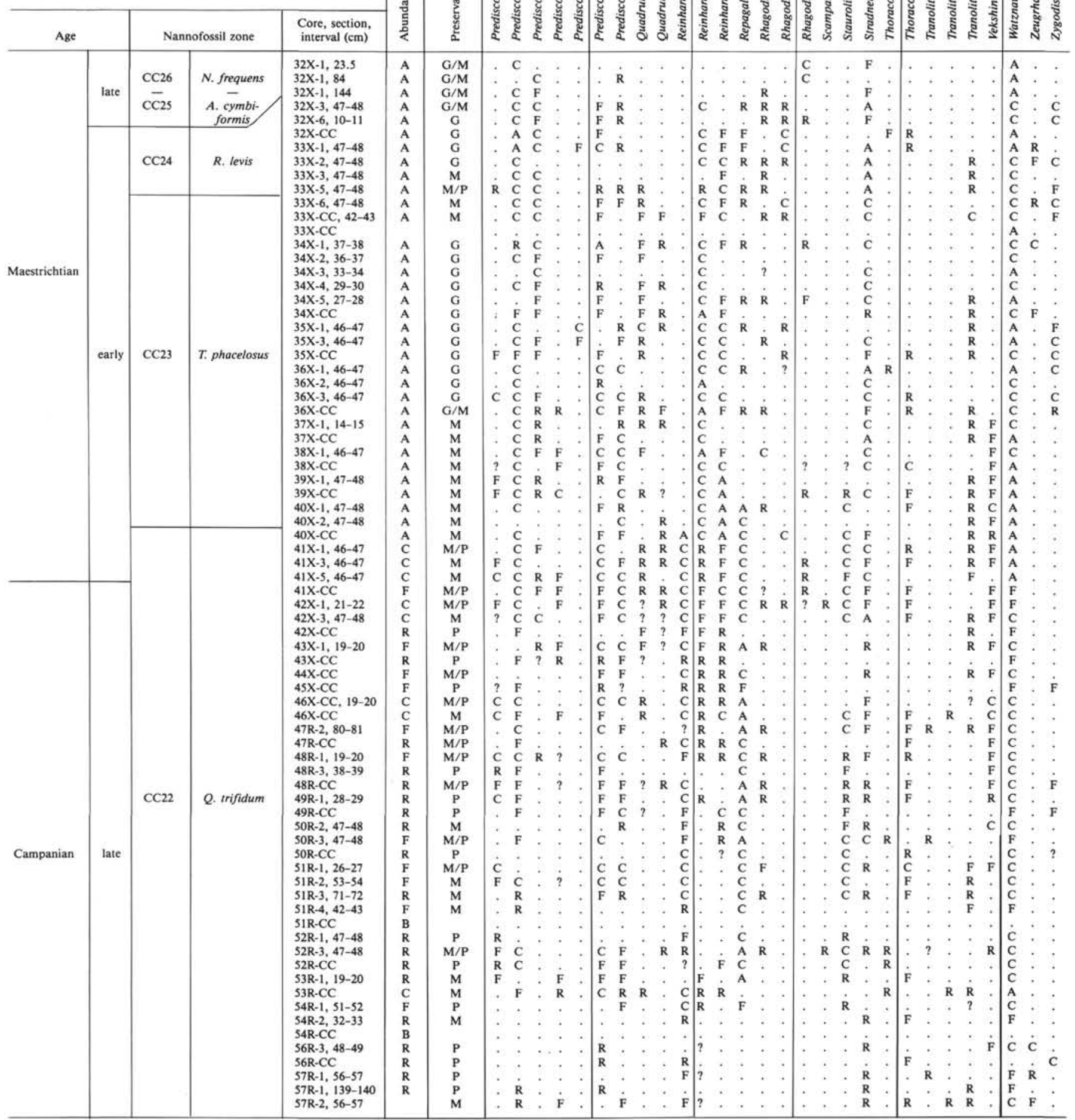




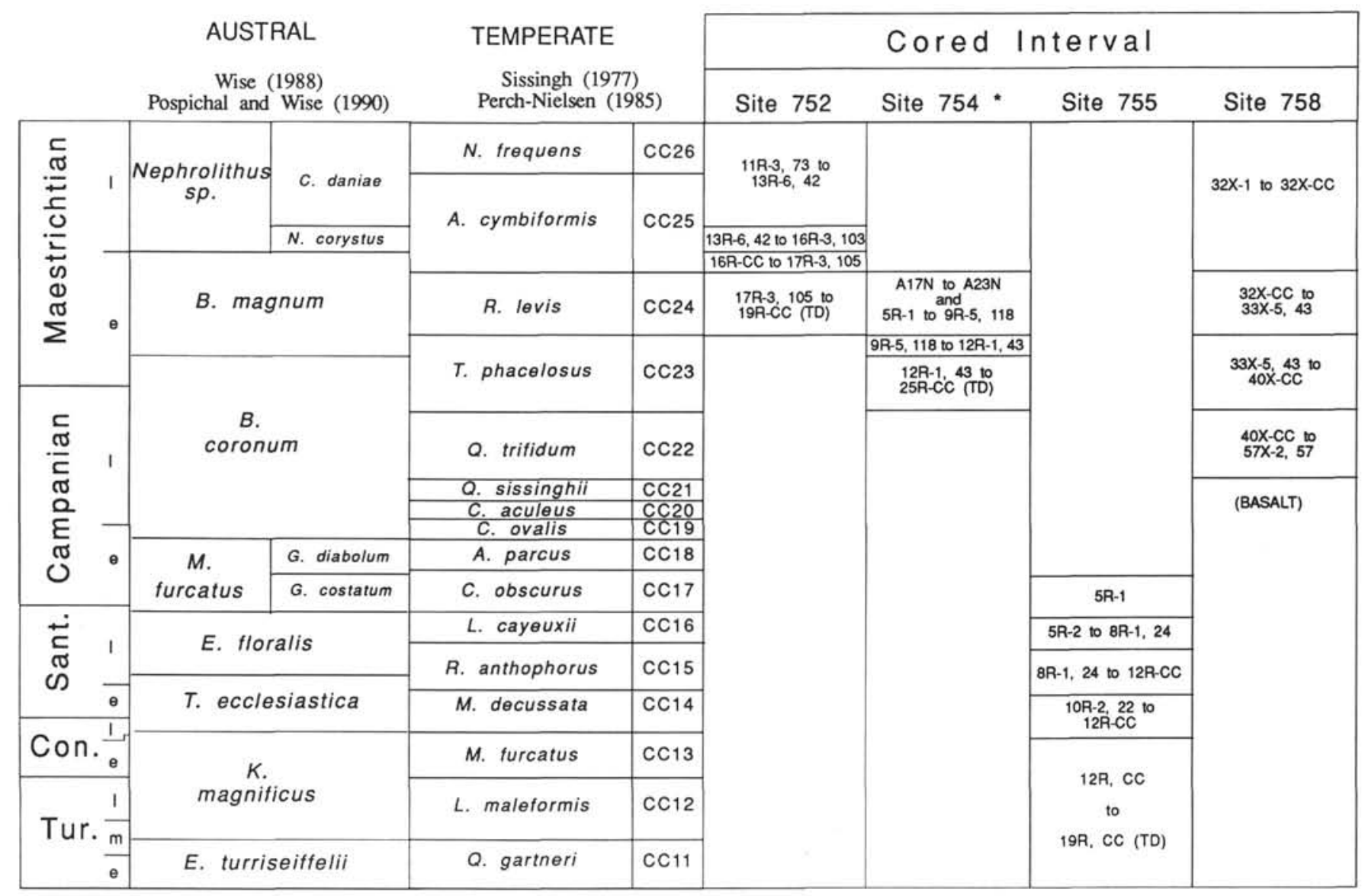

Figure 4. Summary of the nannofossil biostratigraphy for the Cretaceous sediments from Leg 121. For Site 754, cores from Hole 754A are identified with the prefix $A$; cores from Hole 754B have no prefix. 


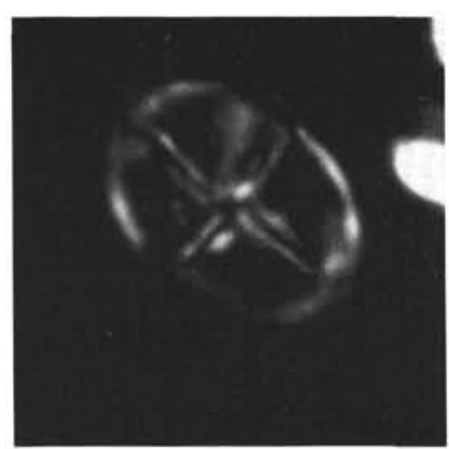

1

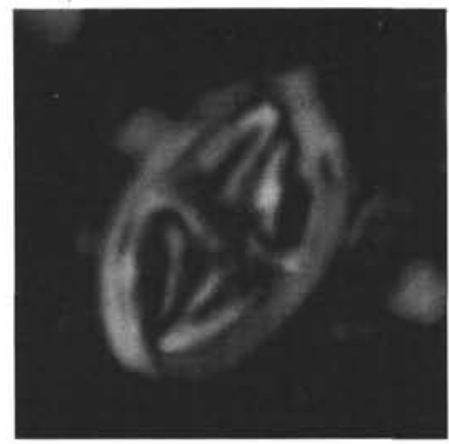

4

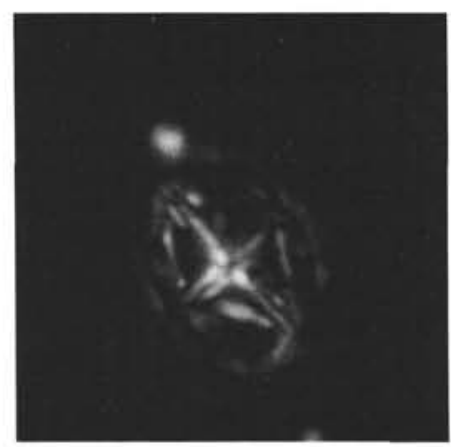

7

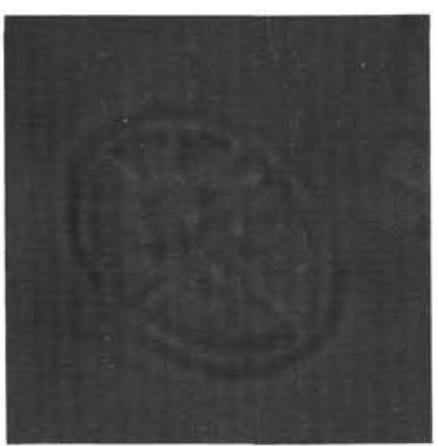

2

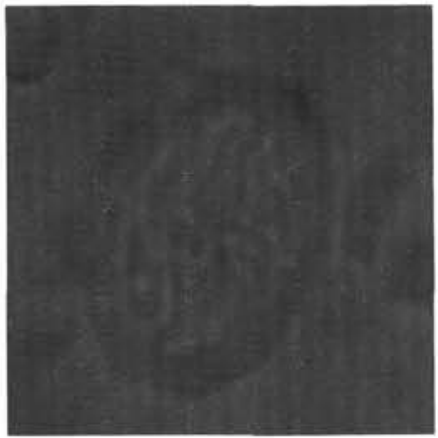

5

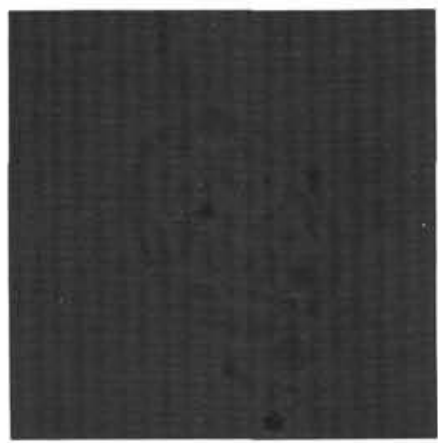

8

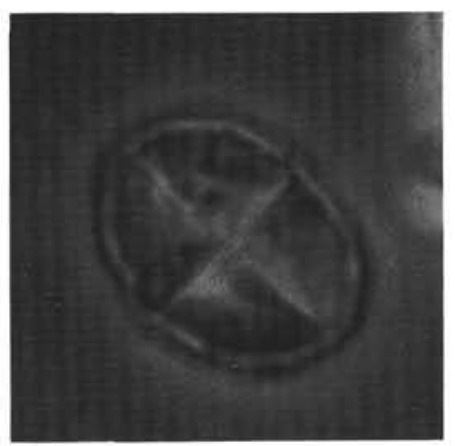

3

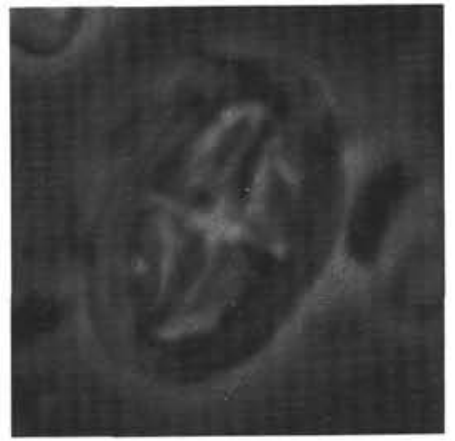

6

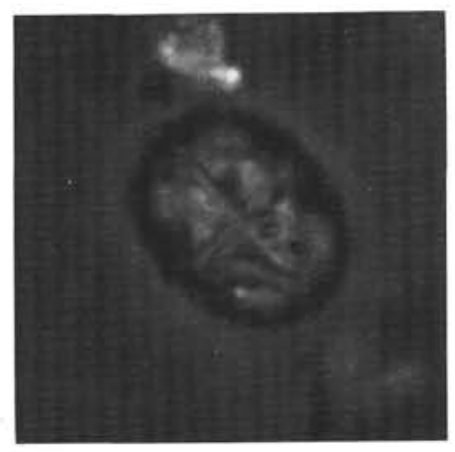

9

Plate 1. 1-3. Misceomarginatus pleniporus, $\times 3000$, Sample 121-758A-36X-CC. 4-6. Monomarginatus quaternarius, $\times 3375$, Sample 121-758A-35X-CC. 7-9. Monomarginatus pectinatus, $\times 3000$, Sample 121-754B-10R-3, 102-103 cm. Figs. 1, 4, 7: polarized light; Figs. 2, 5, 8: transmitted light; Figs. 3, 6, 9: phase-contrast. 


\section{P. RESIWATI}

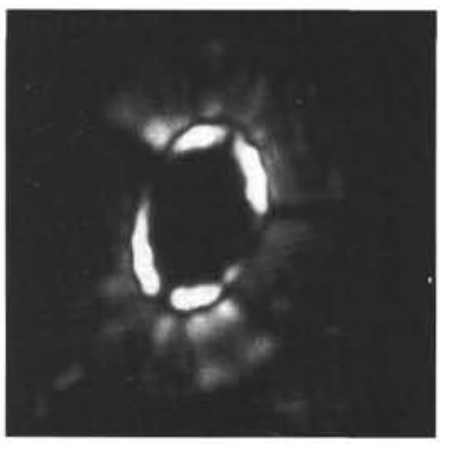

1

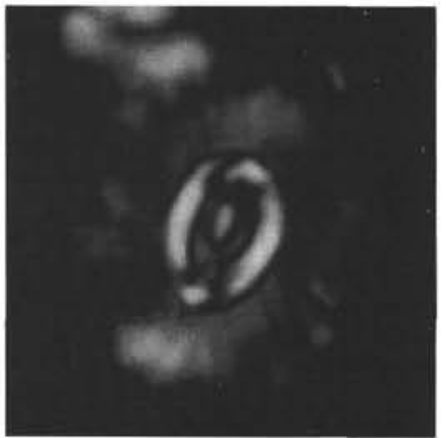

4

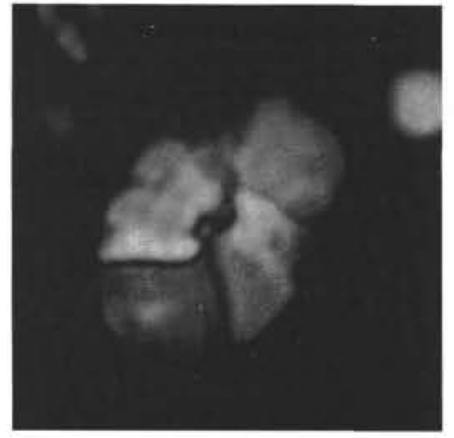

7

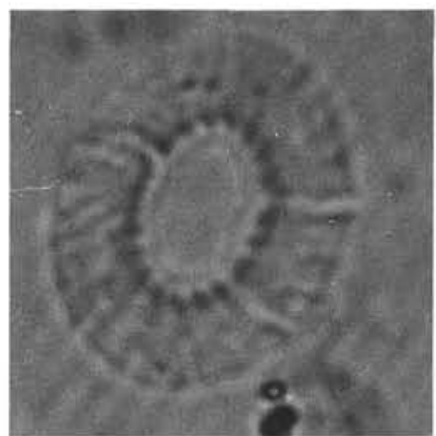

2

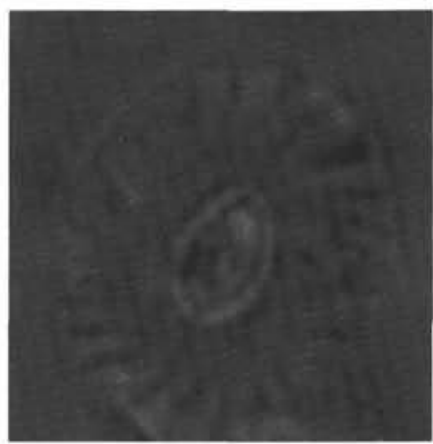

5

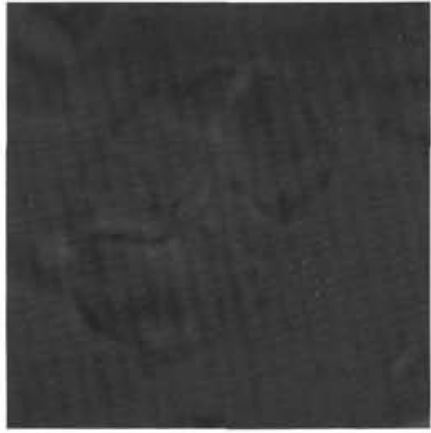

8

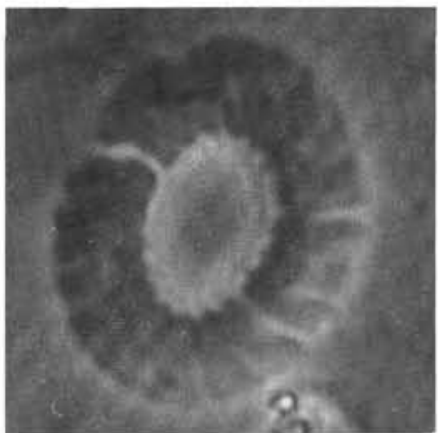

3

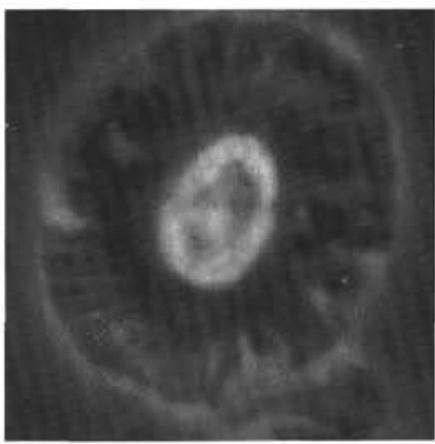

6

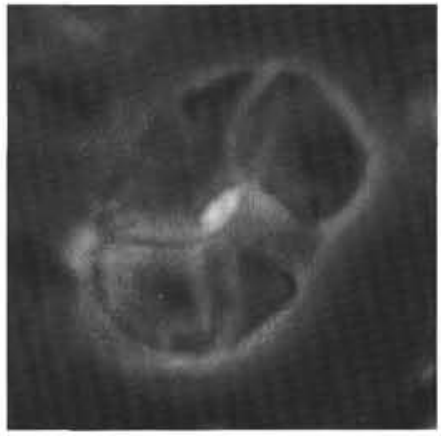

9

Plate 2. All specimens are $\times 3000$. 1-3. Biscutum magnum, Sample 121-758A-52R-1, 47-48 cm. 4-6. Biscutum coronum, Sample 121-758A-43X-1, 19-20 cm. 7-9. Biscutum dissimilis, Sample 121-758A-42X-3, 47-48 cm. Figs. 1, 4, 7: polarized light; Figs. 2, 5, 8: transmitted light; Figs. 3, 6, 9: phase-contrast. 


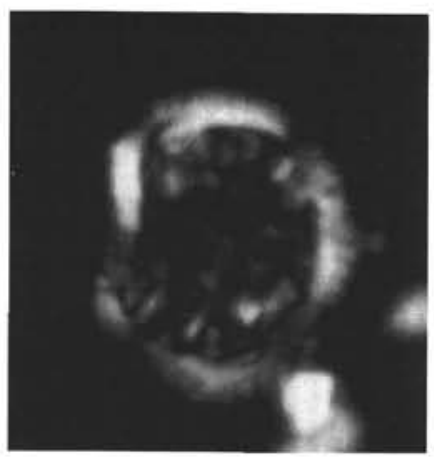

1

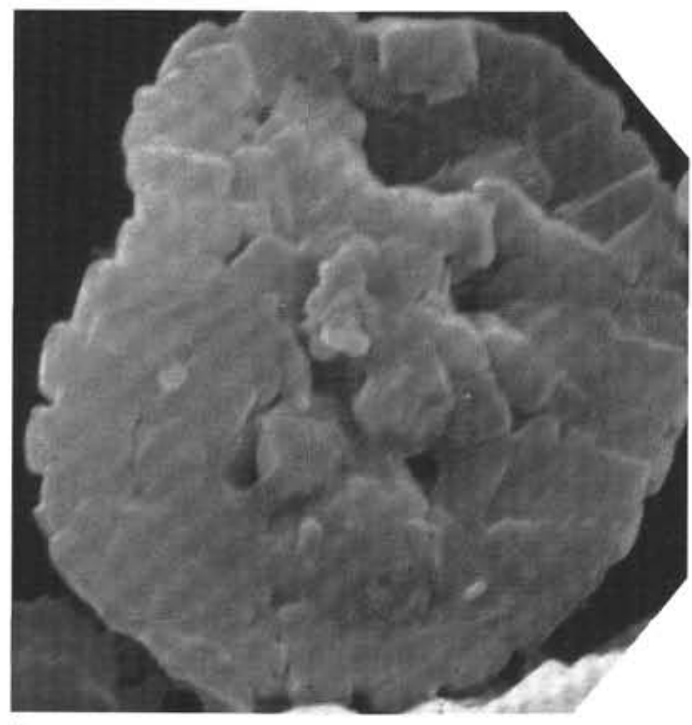

2
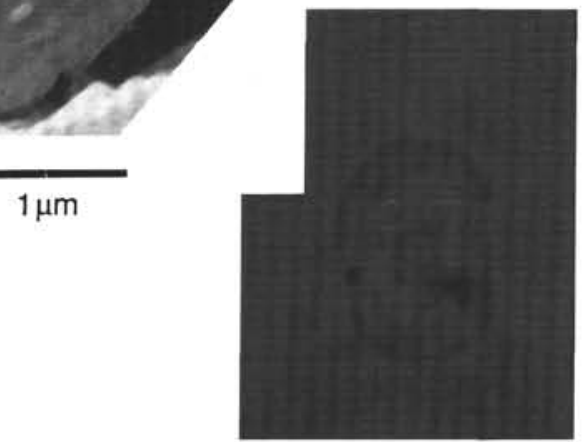

3

4

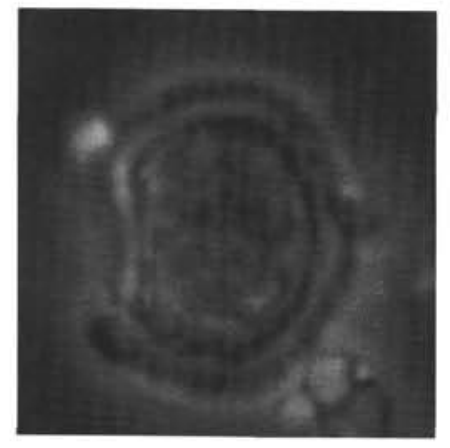

5

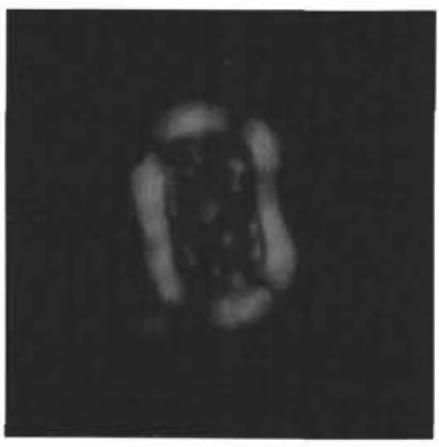

6

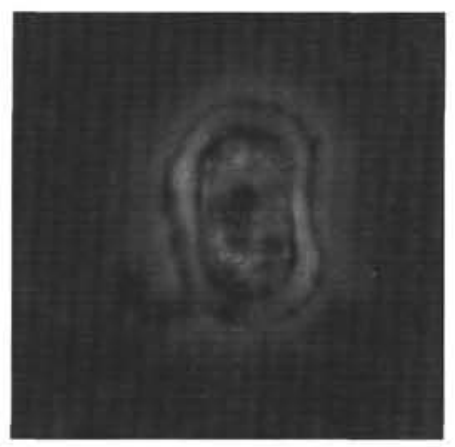

7

Plate 3. 1-4. Nephrolithus frequens, Sample 121-752B-13H-CC. Figs. 1-3: $\times 4125.5-7$. Nephrolithus corystus, $\times 3000$, Sample $121-752 B-17 R-3,105-106 \mathrm{~cm}$. Figs. 1, 6: polarized light; Figs. 2, 5: transmitted light; Figs. 3, 7: phase-contrast; Fig. 4: SEM. 


\section{P. RESIWATI}

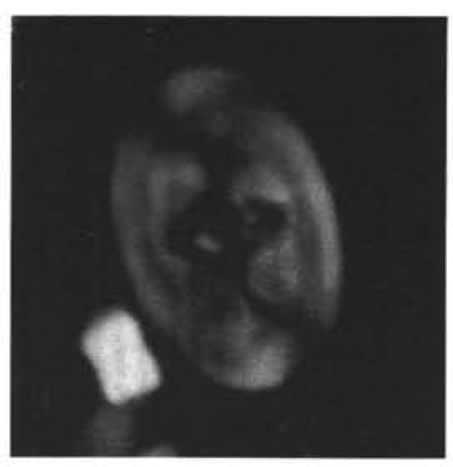

1

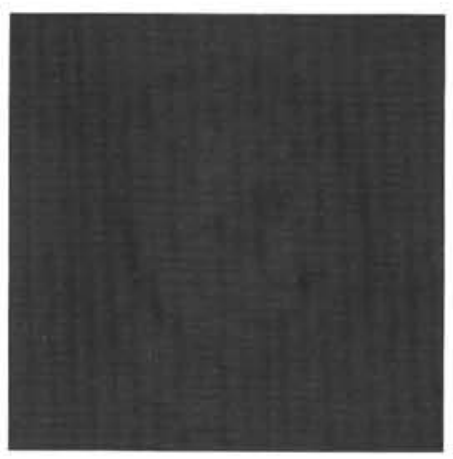

3

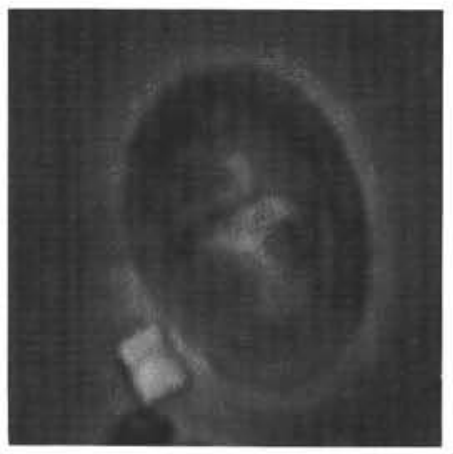

6

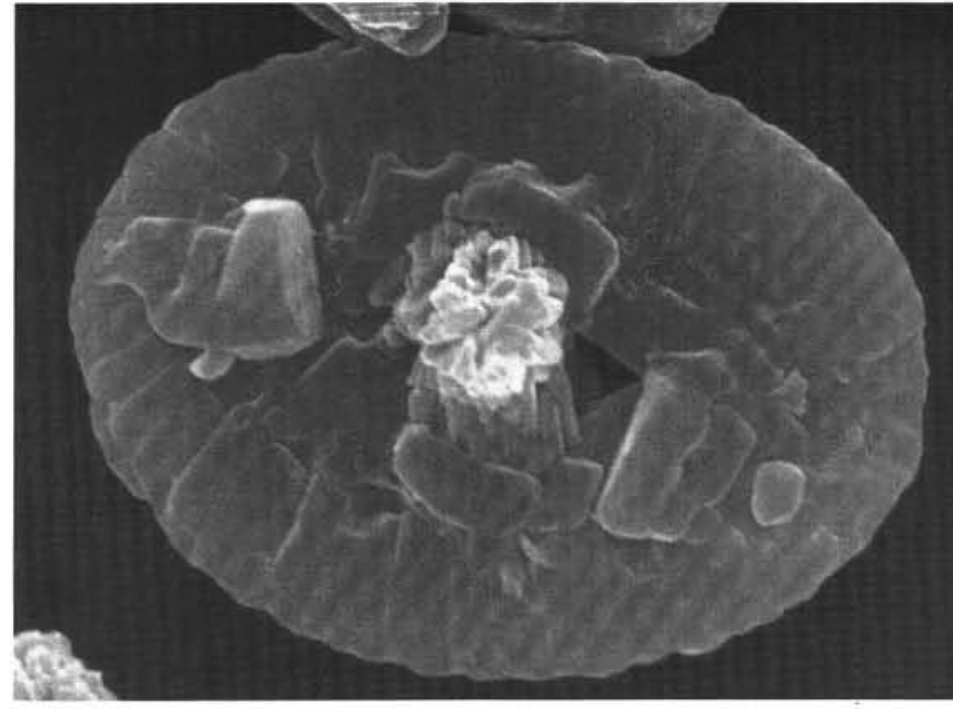

2

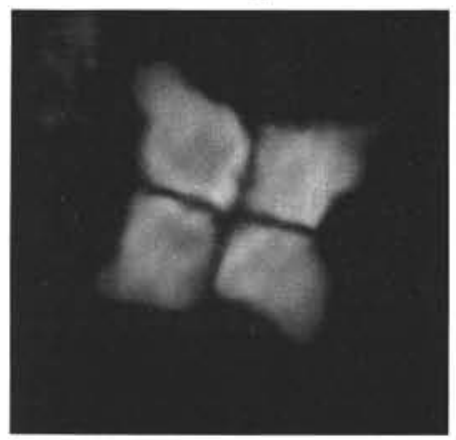

4

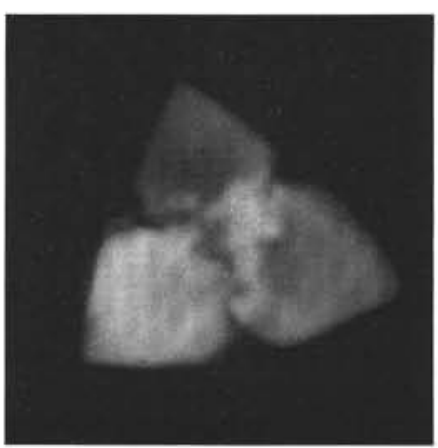

7

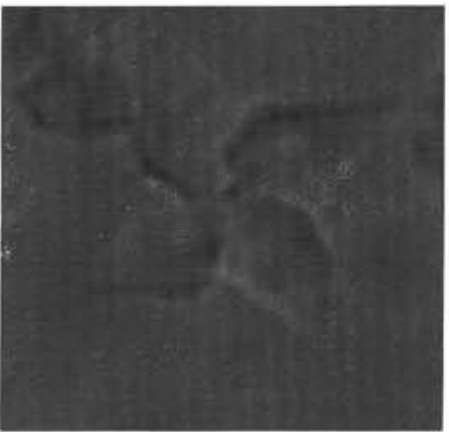

$1 \mu \mathrm{m}$
5

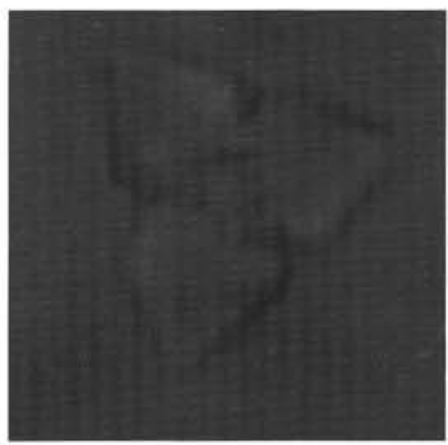

8

Plate 4. All specimens are $\times 3000$, Sample 121-758A-36X-CC, except as noted. 1-3. Reinhardtites levis. 4. R. sp. aff. R. anthophorus, Sample 121-754B-25R-CC. 5, 6. Quadrum sissinghii. 7, 8. Quadrum trifidum. Figs. 1, 5, 7: polarized light; Figs. 2, 6, 8: transmitted light; Fig. 3: phase-contrast; Fig. 4: SEM. 


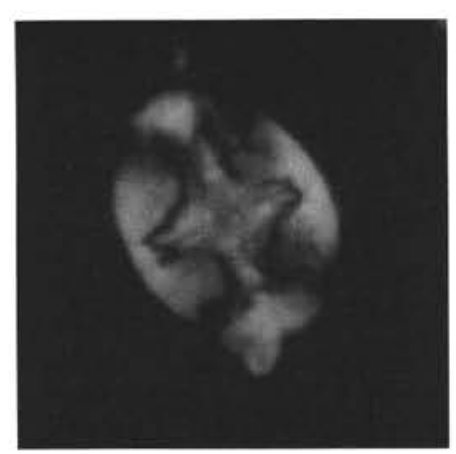

1

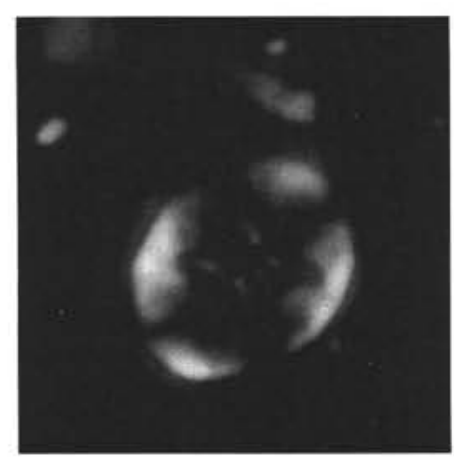

4

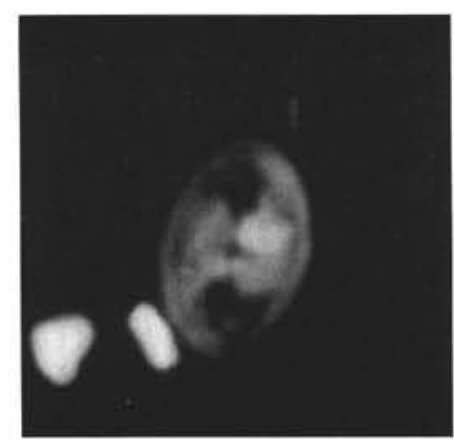

7

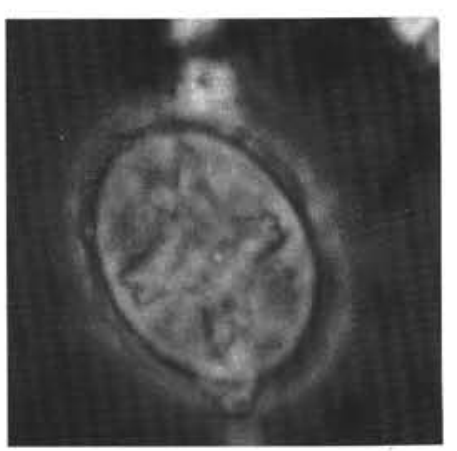

2

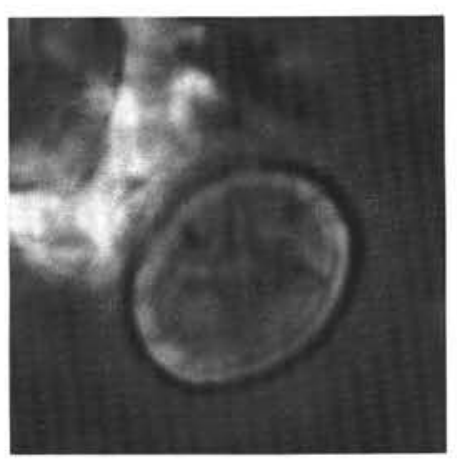

5

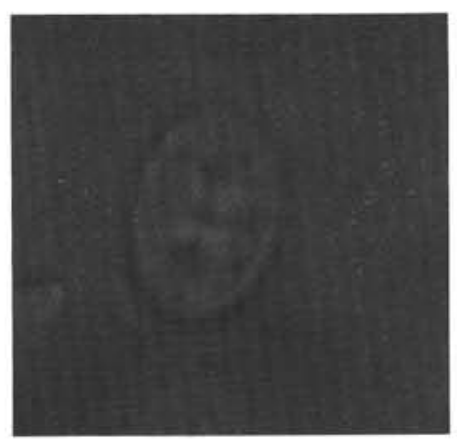

8

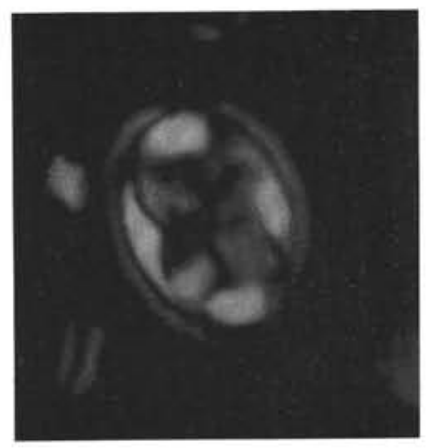

3

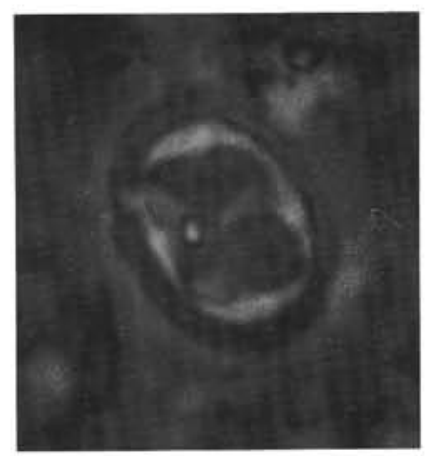

6

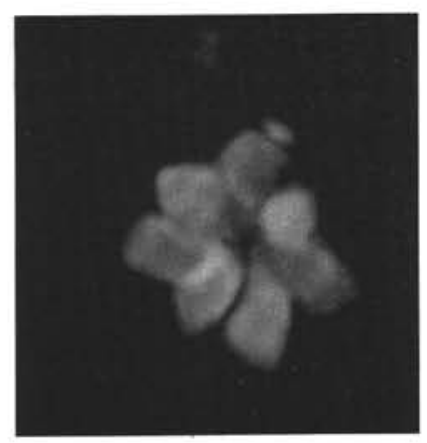

9

Plate 5. 1, 2. Eiffellithus eximius, $\times 2500$, Sample $121-758 \mathrm{~A}-47 \mathrm{X}-2,81-82 \mathrm{~cm} .4,5$. Eiffellithus turriseiffelii, $\times 3000$, Sample $121-758 \mathrm{~A}-41 \mathrm{X}-3,46-47 \mathrm{~cm} .3,6$. Helicolithus trabeculatus, $\times 4000$, Sample 121-755A-8R-CC. 7, 8. Tranolithus phacelosus, $\times 3000$, Sample 121-758A-41X-3, 46-47 cm. 9. Lithastrinus moratus, $\times 3000$, Sample 121-755A-8H-1, 24-25 cm. Figs. 1, 3, 4, 7, 9: polarized light; Figs. 2, 5, 6: phase-contrast; Fig. 8: transmitted light. 


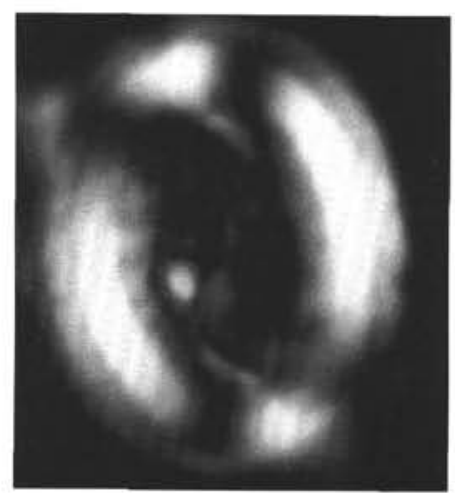

1

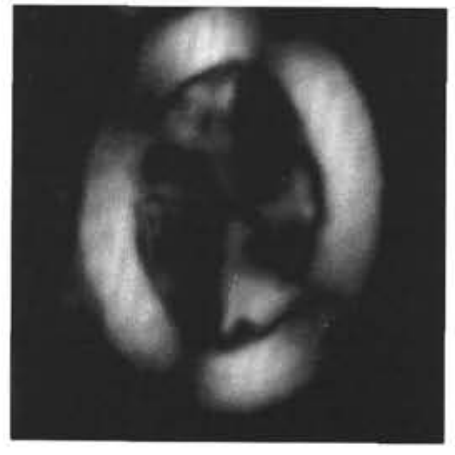

4

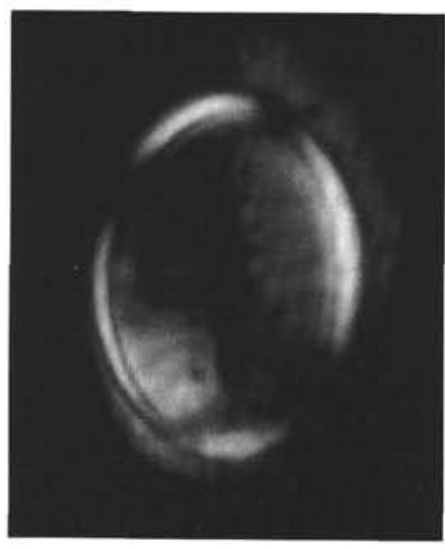

7

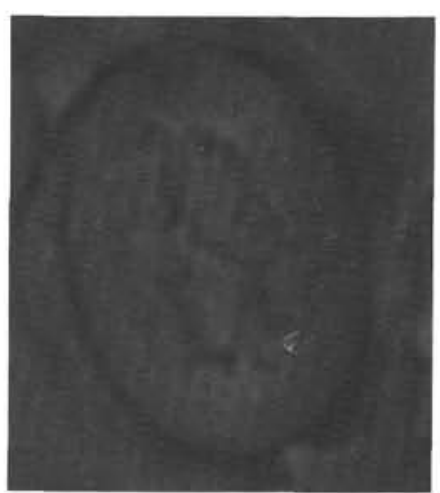

2

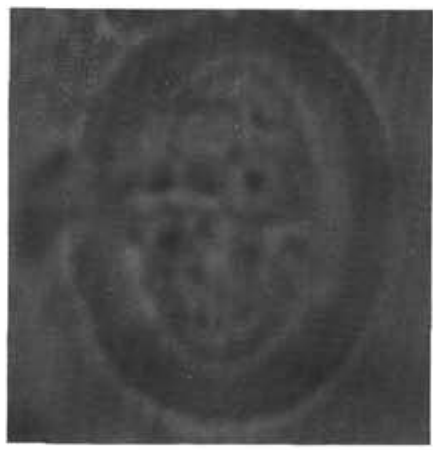

5

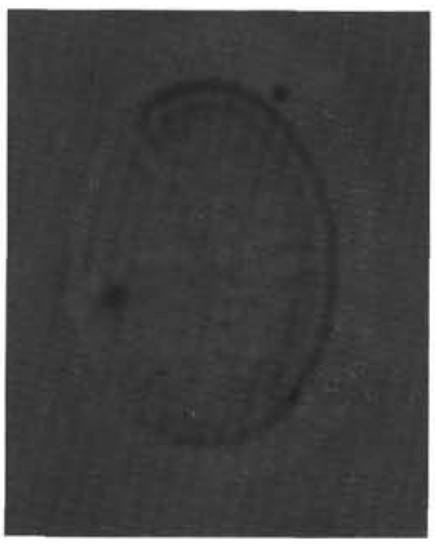

8

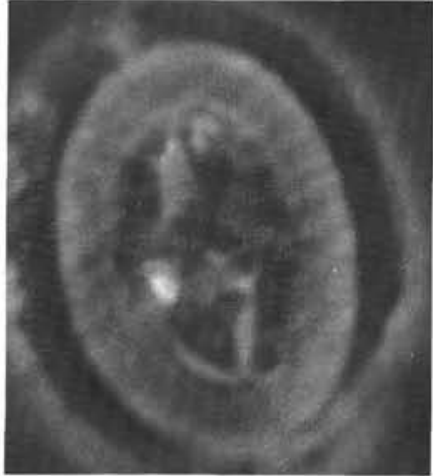

3

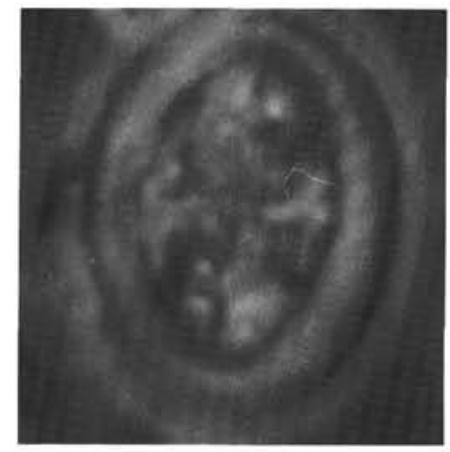

6

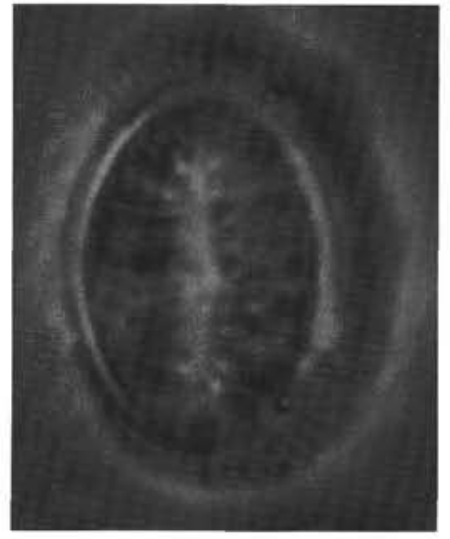

9

Plate 6. 1-3. Aspidolithus parcus constrictus, $\times 3750$, Sample 121-758A-1, 46-47 cm. 4-6. Arkhangelskiella cymbiformis, $\times 3750$, Sample 121-758A-33X-6, 42-43 cm. 7-9. Kamptnerius magnificus, $\times 3000$, Sample 121-758A-49R-1, 28-29 cm. Figs. 1, 4, 7: polarized light; Figs. 2, 5, 8: transmitted light; Figs. 3, 6, 9: phase-contrast. 


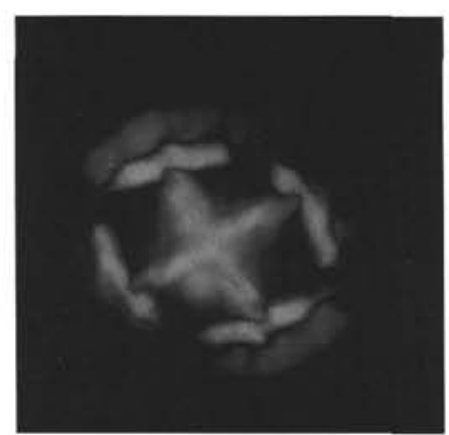

1

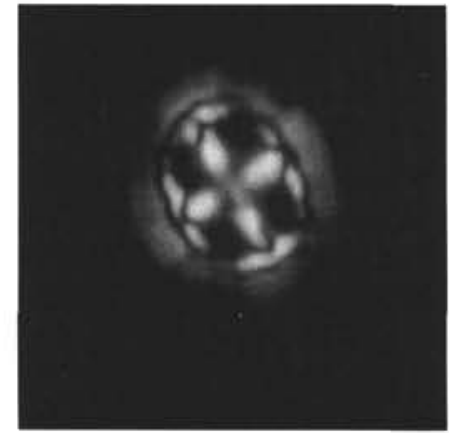

4

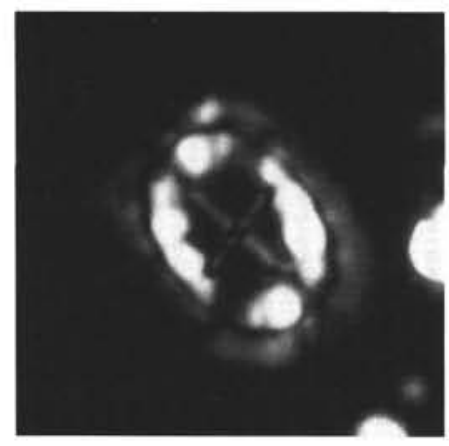

7

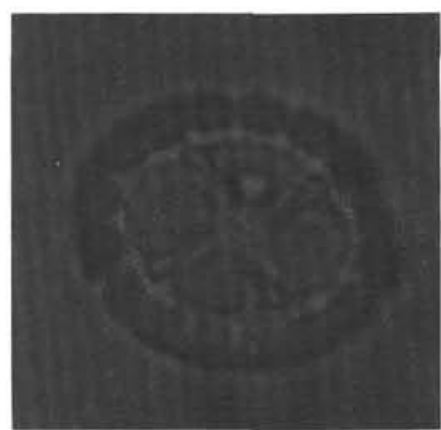

2

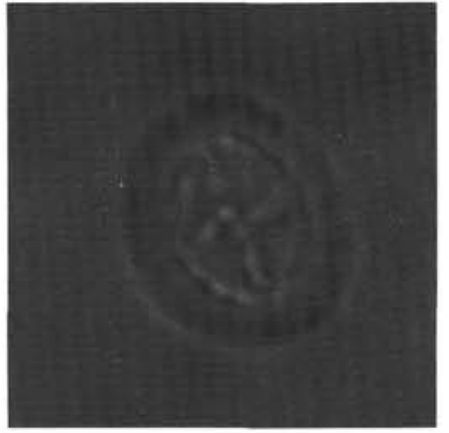

5

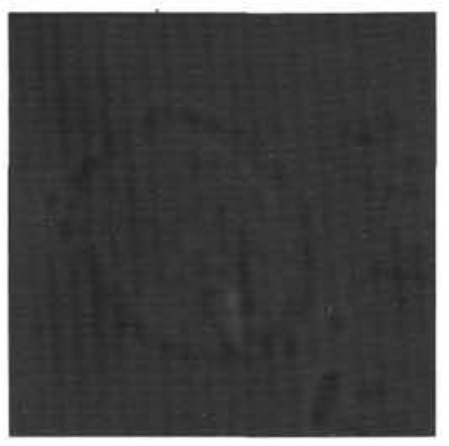

8

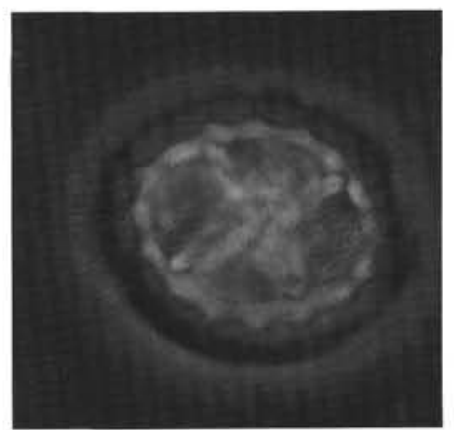

3

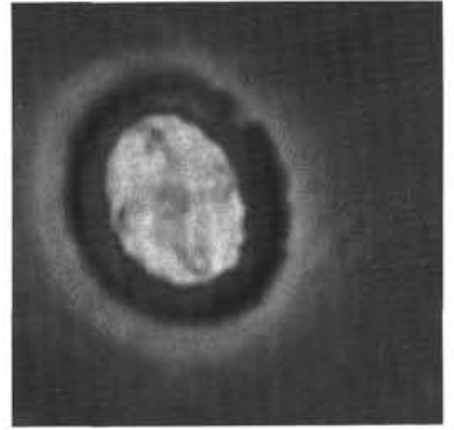

6

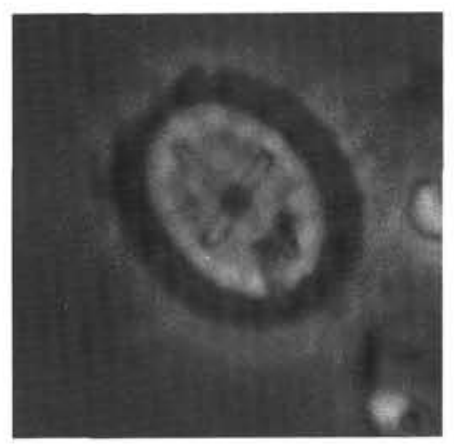

9

Plate 7. 1-3. Prediscosphaera grandis, $\times 2375$, Sample 121-758A-32X-CC. 4-6. Prediscosphaera spinosa, $\times 3000$, Sample 121-758A-36X-CC. 7-9. Prediscosphaera arkhangelskyi, $\times 3000$, Sample 121-758A-32X-CC. Figs. 1, 4, 7: polarized light; Figs. 2, 5, 8: transmitted light; Figs. 3, 6, 9: phase-contrast. 


\section{P. RESIWATI}

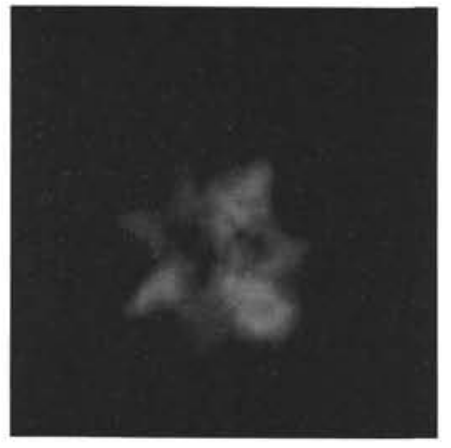

1

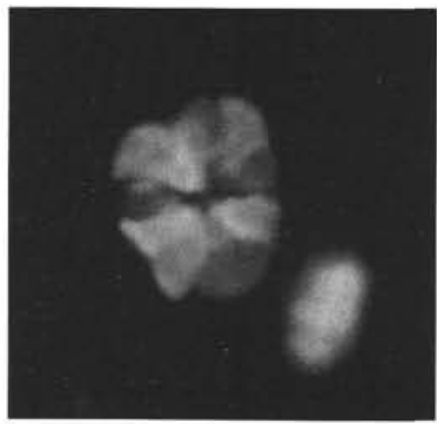

4

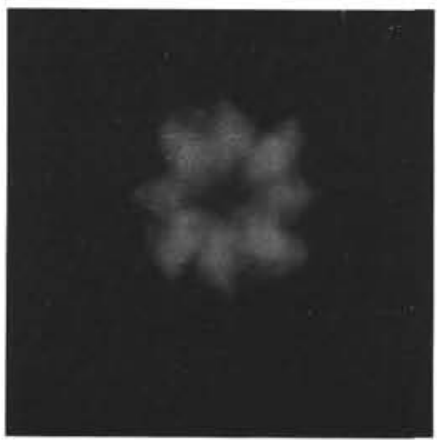

7

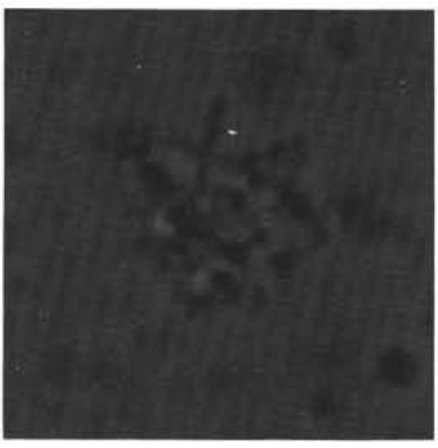

2

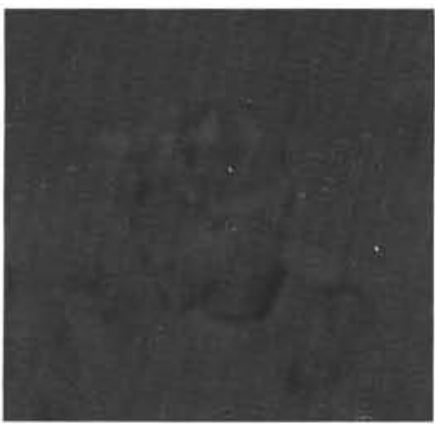

5

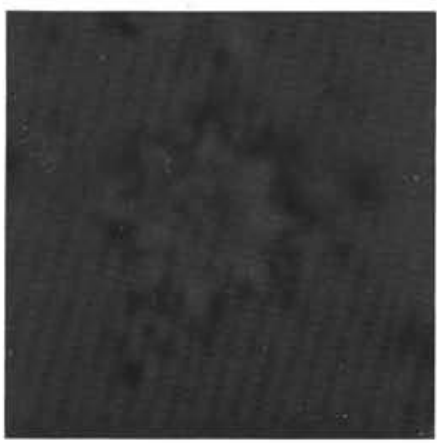

8

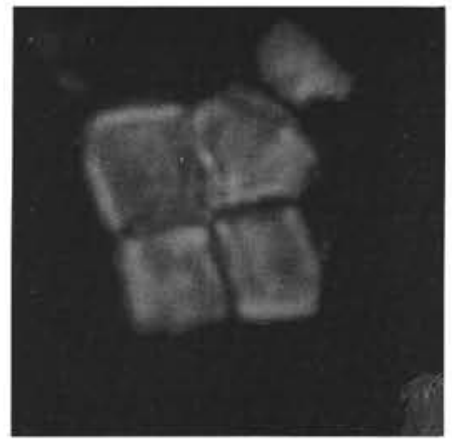

3

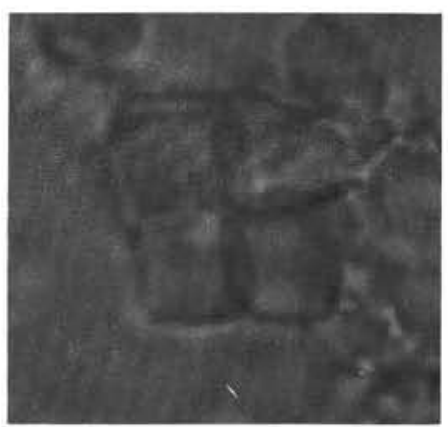

6

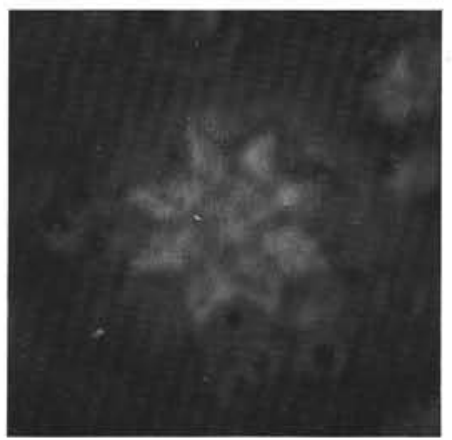

9

Plate 8. 1, 2. Lithastrinus septenarius, $\times 3500$, Sample $121-755 \mathrm{~A}-15 \mathrm{R}-3,82-83 \mathrm{~cm} .4$, 5. Eprolithus $\mathrm{sp} .1, \times 3500$, Sample $121-755 \mathrm{~A}-13 \mathrm{R}-4,49-50 \mathrm{~cm} .3$, 6. Quadrum gartneri, $\times 3750$, Sample 121-755A-12R-CC. 7-9. Eprolithus sp. 2, $\times 3500$, Sample 121-755A-13R-4, 49-50 cm. Figs. 1, 3, 4, 7: polarized light; Figs. 2, 5, 6, 8: transmitted light; Fig. 9: phase-contrast. 